\title{
Précision des enregistrements de houles océaniques
}

\section{Accuracy of ocean wave records}

\author{
PAR R. SILVESTER
}

\author{
A.M.I.E. AUSTR. \\ SENIOR IECTURER IN CIVIL ENGINEERING (HYDRAULICS) UNIVERSITY OF WESTERN AUSTRALIA
}

\begin{abstract}
En présence de la confiance que l'on a dans les appareils enregistreurs de houle, plus particulièrement dans les enregistreurs de pression placés sur le fond de la mer, il est bien légitime de chercher à vérifier l'exactitude du profil qu'ils fournissent, ou de l'analyse harmoniqu'e de ce profil, en le rapportant à l'oscillation de la surface qu'il se propose de représenter. Dans l'article qu'on ba lire, l'auteur examine les différentes sources d'erreurs et recommande le choix de l'emplacement à donner à l'appareil enregistrear pour réduire ces erreurs all minimum. La précision est une condition essentielle lorsque ces chiffres sont utilisés pour établir les équations de prévision de la houle, ou pour estimer l'exactitude des formules existantes. Il exprime le vau que les auteurs traitant de Ia question décrivent les installations qui ont servi it l'enregistrement, ainsi que les mesures adoptées pour éliminer, ou du moins ponr réduire, les erreurs probables.
\end{abstract}

1.

Les quelque cinquante dernières années, pendant lesquelles l'homme a cherché à déceler un semblant d'ordre dans les houles océaniques, ont vu peu de progrès, en raison du manque d'instruments enregistreurs appropriés. Tout au début, on essayait de noter les ondulations de la surface des eaux en rapportant leur niveau à un repère, par exemple un pieu ou une perche baignant dans 9 ou $12 \mathrm{~m}$ d'eau, ou en mesurant les variations de la profondeur avec une jauge à résistances étalonnées [41]. Le premier procédé était fastidieux lorsqu'on l'appliquait à la main et devenait coûteux si l'on utilisait la photographie. Le second souffrait de l'action de la corrosion; parfois aussi, l'appareil était complètement démoli par des vagues de tempête.

\begin{abstract}
With the great faith being placed in ocean wave recorders, particularly the pressure type located on the ocean bed, it is pertinent to investigate the accuracy of the profile obtained, or its harmonic analysis, with reference to the surface oscillation it purports to represent. The various sources of error are discussed and recommandations are made on the location of a recorder in order to minimise these errors. Precision is essential when wave data are to be used for deriving wave forecasting equations, or for comparing the accuracy of existing formulae and a plea is made that authors fully describe recorder installations and the steps taken to eliminate, or at least reduce, the probable errors.
\end{abstract}

1.

For some fifty year's, in which man has endeavoured to observe some semblance of order in ocean waves, little progress was made because of the dearth of suitable recording instruments. Initial attempts to record water surface undulations were made by the observation of water levels against a datum such as a stake or pile located in 30 to 40 feet of water, or by the measurement of fluctuating depths by means of a step resistance gauge [41]. The former method was tedious if carried out manually and expensive if conducted photographically; the latter suffered from the hazards of corrosion and, occasionally, complete destruction when storm waves were present.

Then came the era of the wave-pressure re- 
Vint ensuite l'ère de l'enregistreur à variation de pression, les fluctuations de la pression exercée sur le fond de l'océan à une certaine distance des côtes étant transmises à un appareil enregistreur placé à terre. Ce genre d'instruments présente de nombreuses variantes dont nous ne donnerons pas les détails ici. Il nous suffira de dire qu'on plaçait ces instruments à des profondeurs allant de 12 à $36 \mathrm{~m}$. Associés aux moyens d'analyse dont on dispose actuellement pour séparer les différentes ondes composantes du spectre [5], [30], [31], [45], ces enregistreurs fournissent à peu près tous les éléments permettant de rattacher les vitesses du vent aux houles océaniques qu'elles provoquent. Des données numériques sur les vagues ont pu être obtenues d'une manière analogue pour des ports, ou des points de la côte déterminés, sans qu'on ait à généraliser en admettant les conditions existant en grande profondeur au large des côtes.

Quand l'enregistrement obtenu est utilisé pour fournir des informations sur un endroit déterminé, les inexactitudes qu'il renferme sont möns dangereuses que s'il est considéré comme représentant l'état des choses en eau profonde sur une grande distance le long des côtes, de part et d'autre de l'endroit où a lieu la mesure.

Le présént mémoire a précisément pour objet de signaler les quelques restrictions qu'on doit imposer aux enregistrements de pression de la houle en tant que représentatifs des ondulations de la surface de l'eau. Nombre d'erreurs qui se manifestent s'appliquent aussi bien aux enregistreurs de houle en surface et sont principalement dues à un mauvais choix de l'emplacement.

\section{De la nature des fluctuations de pression.}

La houle progressive, telle que celle que le vent engendre sur l'océan, se propage en eau profonde grâce à un mouvement sensiblement circulaire qu'exécutent les particules liquides. Celles qui se trouvent à la surface décrivent un cercle dont le diamètre est égal à l'amplitude de l'onde (distance verticale séparant la crête du creux), tandis que celles qui se trouvent à une certaine distance sous la surface libre tournent sur des cercles de diamètre moindre; finalement, à une profondeur à peu près égale à la demi-longueur de l'onde, le mouvement devient imperceptible.

Ce mouvement hydrodynamique étant la première cause des fluctuations de la pression en tout point, un enregistreur placé à une profondeur égale ou supérieure à la demi-longueur d'onde d'une houle (de période supposée constante) n'en sera point influencé. Il est également manifeste que des ondes de surface ayant des périodes différentes seront enregistrées avec des coefficients d'amortissement variables. corder in which the fluctuation of pressure on the ocean bed some distance offshore could be transmitted to a shore based recording instrument. There have been many variations on this type of recorder and it is not proposed to discuss such details here. Suffice it to say that they have been placed at depths varying from 40 to 120 feet. 'These recorders, together with the analyses now available for separating the wave components of the spectrum [5], [30], [31], [45], can supply most of the information necessary for relating wind velocities to the ocean waves which they generale. Wave data have also been obtained in a similar manner for particular harbours or points on the coast without recourse to generalising on deep water conditions offshore.

When a record is used to supply "on the spot" information inaccuracies are not so critical as when it is accepted as typical for deepwater conditions along an extensive length of coast, either side of the installation. The purpose of this paper is to outline some of the limitations of pressure wave records in so far as they are taken to indicate undulations at the water surface. Many of the errors which arise apply equally well to surface wave recorders and are due mainly to bad siting of the instruments.

\section{Nature of Pressure Fluctuations.}

The progressive type of wave, such as the wind generated ocean wave, is propagated in deep water by a near circular movement of the water particles. Those at the surface rotate in a circle of diameter equal to the wave height (vertical distance from crest to trough), whilst those at some depth below the surface rotate in circles of smaller diameter, until at a depth equal to approximately half a wave length the motion is imperceptable.

As this hydrodynamic movement is the prime mover of the pressure fluctuation at any point then it is apparent that a recorder located at a depth equal to, or greater than, half the wave length of a train of waves (constant period assumed) will not be actuated. It is equally apparent that surface waves of different periods will be recorded with varying degrees of attenuation.

The approximate relationship of the pressure oscillation at various depths was originally derived by Airy [2] and has been reproduced and used widely ever since. It takes the form:

$$
\frac{\mathrm{H}_{d}}{\mathrm{H}_{s}}=\mathrm{K}=\frac{\lceil\cosh (2 \pi d / \mathrm{L})\rceil(1-Z / d)}{\cosh (2 \pi d / \mathrm{L})}
$$


Airy [2] a été le premier à établir la relation qui existe entre l'oscillation de la pression et la profondeur, relation qui a été souvent reproduite et largement utilisée. Cette relation est la suivante :

$$
\frac{\mathrm{H}_{d}}{\mathrm{H}_{s}}=\mathrm{K}=\frac{\lceil\cosh (2 \pi d / \mathrm{L})\rceil(1-Z / d)}{\cosh (2 \pi d / \mathrm{L})}
$$

où $\mathrm{H}_{a}$ est l'amplitude de la pression, à la profondeur $Z$ en dessous du niveau de l'eau au repos, $\mathrm{H}_{s}$ l'amplitude de la houle en surface, L la longueur d'onde pour une profondeur $d$.

L'enregistreur étant placé sur le fond de l'océan, le facteur de réponse de la pression devient $1 /[\cosh (2 \pi d / \mathrm{L})]$; les différentes valeurs qu'il prendra sont exprimées en «pour cent» sur la figure 1, pour différentes profondeurs et périodes.

La relation ci-dessus s'applique aux ondes sinusoïdales d'amplitude faible par rapport à leur longueur d'onde. Elle s'applique aux ondes engendrées par le vent qui se propagent sous forme de houle, avant que leur cambrure soit augmentée par la diminution de profondeur, ou par toute autre cause. Comme nous le verrons par la suite, son application dans de tels cas pratiques est plutôt discutable.

\section{L'amortissement de la pression.}

On voit, d'après l'expression de $\mathbf{K}$, que sa valeur dépend de la longueur d'onde, laquelle dépend, à son tour, de la période pour une profondeur donnée. Ainsi, en un point donné, l'enregistreur de pression placé au fond notera les ondes de longue période de façon plus conforme à l'aspect qu'elles ont à la surface que les ondes de période courte, En fait, il ne notera pas les ondes de période très courte. Cette reproduction sélective des conditions de surface affecte aussi bien les amplitudes que les périodes.

L'analy'se harmonique d'une onde de structure complexe dévoile la présence d'une bande d'ondes composantes. L'amplitude analysée est la moyenne d'une valeur légèrement variable caractérisant le train d'ondes composant simple de période donnée, chacun de ces trains ayant son propre coefficient d'amortissement correspondant à sa longueur d'onde, pour une profondeur déterminée.

Bien qu'un pareil spectre soit continu entre la période minimum et la période maximum en cause, il est commode de considérer pour le calcul des groupes composants à l'intérieur d'une bande étroite (par exemple avec des intervalles d'une seconde) et d'appliquer le facteur de réponse de pression à de tels groupes, indépendamment les uns des autres. Pierson et Marks [32], where :

$\mathrm{H}_{d}$ is the pressure amplitude at depth $\mathrm{Z}$ below the still water level,

$\mathrm{H}_{s}$ is the surface wave amplitude,

$\mathrm{L}$ is the wave length in water depth $d$.

When the instrument is placed on the ocean bed this pressure response factor becomes $1 /[\cosh (2 \pi d / \mathrm{L})]$ and specific values of it expressed as percentages are graphed in figure 1 for variations in water depth and wave period.

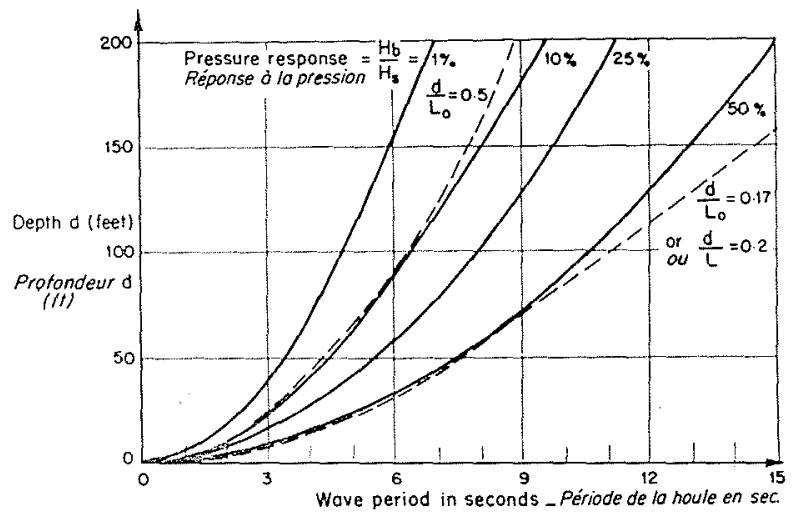

Fig. 1. - Graphique donnant en \% le facteur de réponse à la pression. D'ordinaire, le facteur de réponse $50 \%$ est le minimum admissible dans un enregistrement.

Graph showing percentage pressure response at various depths for different wave periods. Generally $50 \%$ is the minimum response factor accepted in a record.

The above relationship holds for sinusoidal wave forms in which the amplitude is small with respect to wave length. It is applicable to wind generated waves in the form of swell before they are steepened due to shoaling or any other cause. As will be seen from the following sections its application in any such practical conditions is rather questionable.

\section{Pressure Attenuation.}

From the expression for $\mathbf{K}$ it can be seen that its masnitude is determined by the wave length which, for a given depth, is dictated by the wave period. Thus, for a specific location, long period waves will appear in the bottom pressure record nearer the profile of the surface oscillation than the shorter period waves. In fact, very short waves will be omitted altogether. This selective reproduction of surface conditions influences both the wave amplitudes and the wave periods.

When analysed harmonically a complex wave pattern can be shown to have a band of com- 
puis Pierson seul [30], étudiant les spectres d'énergie, où les ordonnées sont proportionnelles aux carrés des amplitudes, ont été amenés à appliquer le facteur de réponse élevé au carré à chaque groupe élémentaire. Le même procédé a été utilisé avec succès par Timme et Stinson [43] dans la prévision des fluctuations de la pression au fond, à partir des données de surface.

Récemment Neumann [29], employant son calcul de spectre, est arrivé aux conclusions suivantes : « A mesure que la profondeur augmente, l'énergie de la houle baisse rapidement à l'extrémité «période courte du spectre», surtout dans la couche supérieure près de la surface, tandis que la bande optimum, qui concentre la majorité de l'énergie spectrale, glisse vers les basses fréquences à mesure que le spectre se rétrécit. 》 Il dit également : «La diminution de l'énergie totale de la houle avec la profondeur diffère beaucoup selon qu'il s'agit du mouvement composé de plusieurs ondes d'une mer «saturée », ou d'une seule onde harmonique, représentant à la surface une énergie totale équivalente. »

Ces conclusions cadrent avec les constatations faites par différents expérimentateurs, pendant des années, mais, jusqu'à ce jour, on n'a pas eu de résultats pratiques pour confirmer les équations de Neumann.

Avant l'application de l'analyse harmonique, on considérait la période de la houle comme l'intervalle de temps compris entre les crêtes ou les creux successifs d'un enregistrement, ou encore comme les intersections successives des parties montantes du graphique avec l'horizontale représentant l'eau au repos. Or, Bowden [6], Pierson [30] et Seiwell [38] ont constaté que cette « période » de la pression mesurée audessous de la surface était plus longue que la «période » de l'oscillation à la surface. Plus l'enregistreur était placé profondément, plus forte était l'erreur.

Cette imprécision dans la définition de la période de la houle a introduit des erreurs dans l'application du facteur de réponse à la pression; aussi, la comparaison de l'amplitude en surface et de l'amplitude de la pression sous la surface a-t-elle conduit dans le passé à des conclusions extrêmement dissemblables.

La pratique généralement suivie consiste à adjoindre un coefficient empirique au facteur de réponse à la pression, comme l'ont fait Folson [13], [15], Morison [28] et Seiwell [38], [39], [40]. Snodgrass [41] a réuni les différentes valeurs obtenues pour ce coefficient; elles oscillent entre 1,07 et un peu plus de 1,2. La valeur de 1,35 donnée par Seiwell [38] a été corrigée par Ewing et Press [12] et par Folsom [14] pour le cas des eaux peu profondes. Dans la notice concernant son nouvel enregistreur automatique ponents. The analysed height is an average of a slightly fluctuating value for that particular period component wave train, each of which has its own attenuating coefficient corresponding to its wave length in a specific depth of water.

Although such a wave spectrum is continuous from the minimum to the maximum wave period present, it is useful in calculations to consider group components within a narrow band limit (say 1 second intervals) and apply the pressure response factor to such groups independently. Pierson and Marks [32] and then Pierson [30], working with energy spectra, i.e. ordinates proportional to (wave height) ${ }^{2}$, were required to apply the square of the pressure response factor to each elemental group. Their method has been applied with some success by Timme and Stinson [43] in predictions of boltom pressure fluctuations from surface wave information.

Recently Neumann [29], employing his spectral analysis, has arrived at the following conclusions: "With increasing depth, the wave energy attenuates rapidly at the low-period end, especially in the upper layer beneath the surface, and the optimum band, where most of the spectral energy is concentrated, shifts towards lower frequencies as the spectrum narrows" and "There is a great difference in the decrease of the total wave energy with depth between the composite wave motion of a fully arisen sea and a simple harmonic significant wave of equivalent total energy at the surface." These conclusions fit the picture obtained by various experimenters over the years, but to date the equations derived by Neumann have not been verified by any practical results.

Until harmonic analysis was possible the wave period was taken to be the time interval between successive crests or troughs of the record, or, alternatively, successive intersections of the upstrokes of the record with the still water datum line. It was found by Bowden [6], Pierson [30] and Seiwell [38], that this "period" of the subsurface pressure was greater than the "period" of the surface oscillation. The deeper the recorder the larger the error.

This lack of definition in the wave period has caused erroneous application of the pressure response factor and so comparisons of surface and subsurface pressure amplitudes in the past have suffered extreme variability.

The general practice has been to introduce an empirical coefficicnt with the pressure response factor as instanced by the researches of Folsom [13, 15], Morison [28] and Seiwell [38, 39, 40]. Snodgrass [41] has summarised the many values obtained for this coefficient, which have varied from 1.07 to just over 1.2. Seiwell's value of 1,35 [38] has been corrected by Ewing and 
de houle [49], le Laboratoire National d'Hydraulique propose le coefficient 1,25.

Le côté mathématique de la question n'a pas été négligé et l'on a essayé différentes méthodes pour déduire les pressions sous la surface d'après une oscillation en surface donnée, et vice versa. Fuchs $[16]$ a été amené à conclure que, « alors qu'il est possible de calculer avec une grande exactitude les pressions au fond d'après un enregistrement à la surface, l'opération inverse conduit à une indétermination. »

La seule conclusion valable est que, à présent, il n'existe pas de méthode pour convertir les fluctuations de la pression infra-superficielle en ondulations de surface avec plus de $25 \%$ d'exactitude. Sans parler des erreurs susdites dans la détermination de la période, un grand nombre d'autres erreurs, parmi celles dont il sera question dans ce qui suit, ont probablement affecté les expériences jusqu'ici; on n'a donc pu établir complètement l'exactitude du facteur de réponse à la pression. En attendant, on ne saurait prétendre que l'outil mathématique linéaire peut être appliqué sans réserve à un problème non linéaire.

Il semble évident que la réduction des erreurs au minimum exige une analyse des enregistrements permettant d'appliquer le facteur de réponse à la pression aux trains d'onde composants dans le calcul de l'amplitude de la houle en surface. En raison de la différence de phase existant entre les bandes de période à la surface et sous la surface, il peut être nécessaire d'appliquer les corrections indiquées par Neumann [29].

\section{Fond meuble.}

Quand le fond de la mer est recouvert d'une bonne épaisseur de vase ou d'algues marines, les fluctuations de la pression mesurées par un enregistreur d'ondes placé sur ce support semifluide ne seront pas les mêmes que si le fond était ferme. Pour un fond de ce dernier genre, le coefficient d'amortissement de la pression pourra être posé égal à $1 / \cosh (2 \pi d / \mathrm{L})$, dans la limite des conditions résumées aux chapitres 2 et 3 ci-dessus. D'autre part, dans le cas d'un fond «fluide », cas correspondant à une couche fluide dont l'épaisseur serait grande comparativement à la longueur d'onde, il s'exprime rait mieux par $e^{-2 \pi d / L_{0}}$ (voir plus loin les notations). Stokes [42] a été le premier à traiter le problème des deux couches de fluide dont une analyse est donnée dans le traité de Lamb [24], p. 372 .

Ewing et Press [12] remarquèrent que les valeurs données par Seiwell [39] sont comprises entre les limites définies par les deux fac-
Press [12] as well as Folsom [14] for the shallow water conditions experienced. In the handbook for its new automatic wave recorder [49] the Laboratoire National d'Hydraulique suggests a coefficient of 1.25 .

The problem has not been neglected mathematically and methods have been tried for predicting subsurface pressures from a given surface oscillation and vice versa. Fuchs [16] was led to the conclusion that "While it is possible to compute a bottom pressure record from a surface record with great accuracy, the inverse operation is not uniquely possible."

No other conclusion can be justified than that, at present, there is no method available for converting subsurface pressure fluctuations into the corresponding surface undulations with an accuracy better then $25 \%$. Besides the error of wave period definition mentioned above, it is probable that many of the errors discussed below have entered into the tests carried out so far, so that a complete check upon the validity of the pressure response factor has not been made. Until this is done it will not be known whether this linear mathematical tool can be applied unreservedly to a non linear problem.

It seems apparent that to reduce errors to a minimum, wave records should be analysed so that the pressure response factor can be applied to the component wave groups when calculating the surface wave height. The phase shift between the surface and subsurface periods bands may require the application of corrections outlined by Neumann [29].

\section{Non-rigid Bottom.}

Where the sea bed is covered by a substantial depth of mud or seaweed, the pressure fluctuation measured by a wave recorder placed on this fluid-like support will differ from that obtained if such a "bed" were rigid. The pressure attenuation factor for a rigid bottom might be considered as $1 / \cosh (2 \pi d / \mathrm{L})$ for the limited conditions as outlined in sections 2 and 3 . On the other hand, that for a "fluid" bottom, defined as the case where the fluid layer thickness is large compared with the wave length, is given more closely by $e^{-2 \pi d / L_{0}}$ (for notation see below). Stokes [42] was first to treat the two layer problem and an analysis is available in Lamb [24] p. 372.

Ewing and Press [12] pointed out that Seiwell's data [39] fell between the boundaries set by the two factors. Subsequently, Abramson and 
teurs. Plus tard, Abramson et Bretschneider [1] recommandèrent une valeur moyenne telle que :

$$
\begin{aligned}
& \mathrm{K}^{\prime \prime}=\frac{\mathrm{K}+\mathrm{K}^{\prime}}{2} \\
& =\frac{1}{2}\left[\frac{\cosh [2 \pi(1-Z) / \mathrm{L}]}{\cosh (2 \pi d / \mathrm{L})}+\frac{e^{\left[2 \pi(1-Z) / \mathrm{L}_{0}\right]}}{e\left[2 \pi d / \mathrm{L}_{0}\right]}\right]
\end{aligned}
$$

$Z$ étant la profondeur à laquelle on trouve l'enregistreur mesurée à partir de la surface, L la Iongueur d'onde à la profondeur $d$ et $\mathrm{L}_{0}$ la longueur d'onde en profondeur infinie.

Cette courbe semble cadrer fort bien avec les valeurs de Seiwell, mais il conviendrait de la vé-
Bretschneider [1] suggested the use of a mean value, such that:

$$
\begin{aligned}
\mathrm{K}^{\prime \prime} & =\frac{\mathrm{K}+\mathrm{K}^{\prime}}{2} \\
& =\frac{1}{2}\left[\frac{\cosh [2 \pi(1-Z) / \mathrm{L}]}{\cosh (2 \pi d / \mathrm{L})}+\frac{e^{\left[2 \pi(1-Z) / \mathrm{L}_{0}\right]}}{e^{\left[2 \pi d / \mathrm{L}_{0}\right]}}\right]
\end{aligned}
$$

where :

$Z$ is the depth of the recorder from the surface;

$\mathrm{L}$ is to wave length in depth $d$;

$\mathrm{L}_{0}$ is the deep water wave length.

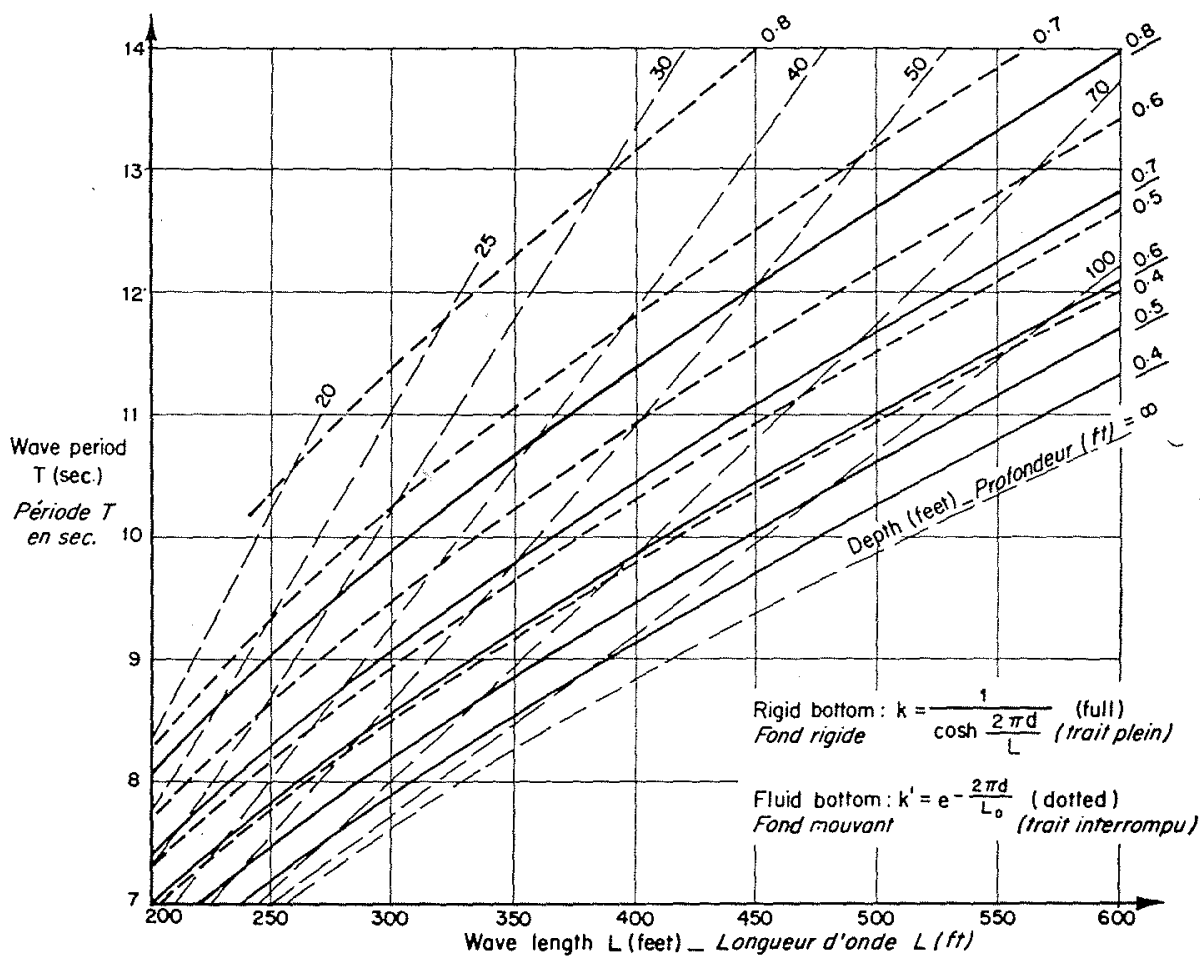

Fra. 2, - Facteurs de réponse à la pression pour des conditions aux limites correspondant à un fond rigide et à un fond mouvant.

pressure response factors for boundary conditions of rigid and "fluid" ocean bed.

rifier plus à fond avant de l'adopter pour l'usage courant. Il y a cependant lieu de noter que les valeurs obtenues seront bien plus souvent à l'intérieur de ces limites qu'au dehors. (Sur la figure 2 , les limites sont marquées pour différentes valeurs de la période, de.la longueur d'onde et de la profondeur.)

Un autre phénomène, qui se rattache étroitement au précédent, est celui des sédiments en suspension, dus à la saltation et à d'autres causes, et pouvant créer, au-dessus de l'enregistreur d'ondes placé sur le fond de l'océan, une couche dense de liquide. Un calcul préliminaire indique que les fluctuations de la pression sont in-
Although this curve appears to fit Seiwell's data quite well, it would require more extensive verification before it could be adopted as a standard procedure. Nevertheless, it is worthy of note that values should occur more readily between these boundaries than outside of them. (The boundaries are marked in figure 2 for various values of wave period, wave length and water depth.)

Another phenomenon, closely allied to the above, is that of sediment suspension, due to saltation and other causes, which may produce a dense layer of liquid above a wave recorder 
fluencées par une pareille couche; néanmoins, le sujet mérite d'être étudié plus à fond.

\section{Cambrure de la houle.}

Comme nous l'avons signalé au début du chapitre 2, le coefficient d'amortissement a été déterminé pour une onde de forme sinusoïdale et il s'applique aussi à la houle aux premiers stades de son évolution en eau peu profonde. Quand il y a raidissement du profil, comme dans une eau très peu profonde ou à l'intérieur de la zone de génération de la houle, des facteurs du second ordre apparaissent, qu'on ne peut mâ̂triser facilement avec un outil mathématique de calcul linéaire.

Seiwell $[38,39,40]$ constate que, même dans une eau de $25 \mathrm{~m}$ de profondeur, la cambrure des vagues longues affectait les résultats auxquels il était arrivé. Morison [28] obtenait avec la placed on the ocean bed. Initial calculations indicate that the pressure fluctuations are influenced by such a layer, but the subject warrants a thorough investigation.

\section{Wave Steepness.}

As mentioned in Section 2 the attenuation factor has been determined for a sinusoidal wave form and is applicable to swell in the early stages of shallow water transformation. In cases where steepening occurs, such as in very shallow water or within an area of wave generation, quantities of second order arise which cannot be readily corrected by a linear mathematical tool.

Seiwell $[38,39,40]$ found that even in 75 feet of water the steepness of the long waves affected his results. Morison [28] in his model experiments obtained reasonable results from the

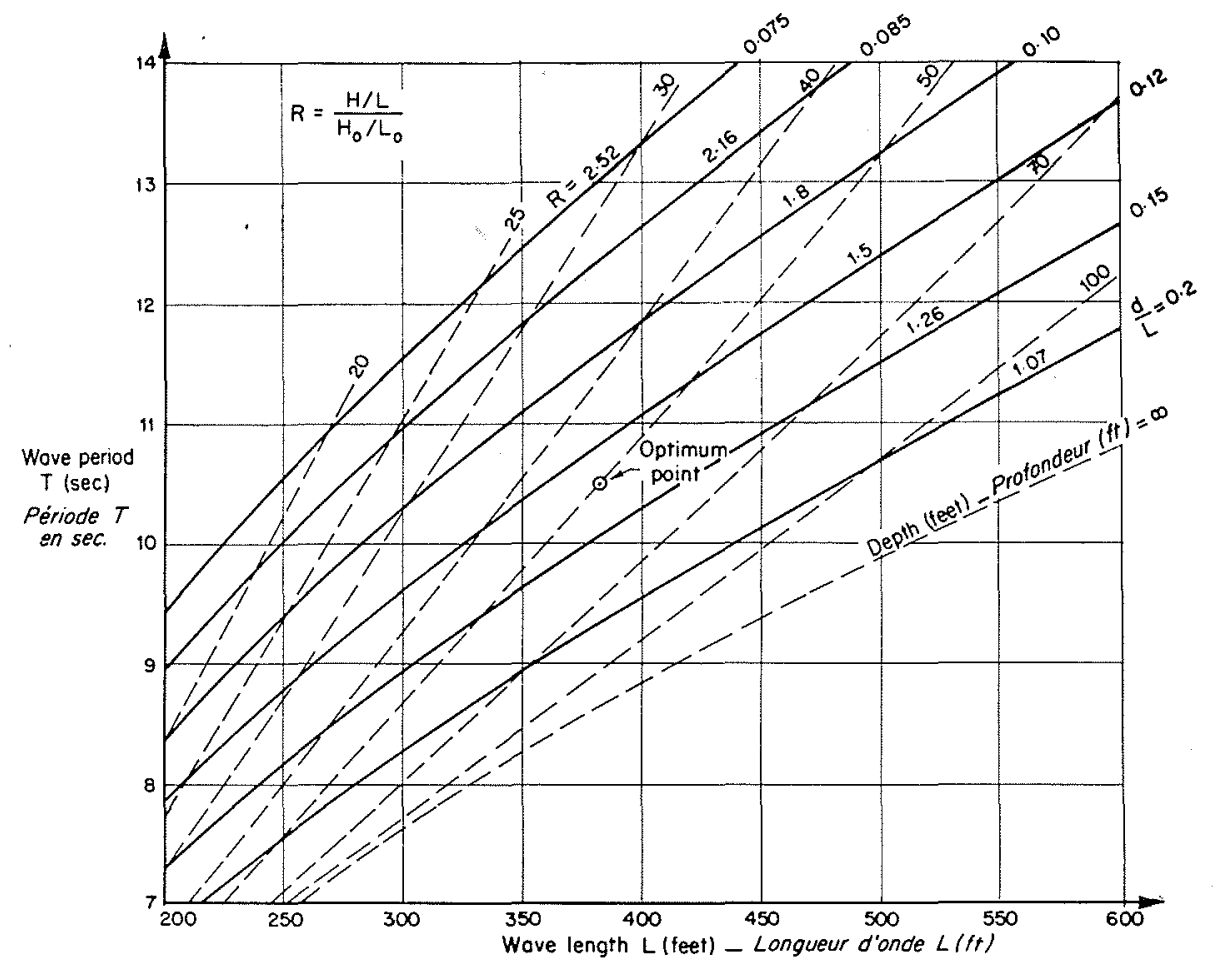

FIG. 3. - Rapport entre la cambrure pour diverses profondeurs

et la cambrure en eau profonde, pour des périodes et des profondeurs donnés.

Ratios of steepness at various depths to the steepness in deepuater for given wave periods and depths of water.

théorie linéaire des résultats satisfaisants dans ses expériences sur modèles, jusqu'à la valeur $(d / L)=0,2$, pour laquelle la cambrure s'accentue. On s'en rend compte sur la figure 3, qui donne la cambrure pour des valeurs données de $d / L$.

Le même auteur a constaté que si l'erreur linear theory down to a value of $(d / L)=0.2$, at which steepening just commences. This can be seen in figure 3 which gives values of steepness for specific values of $d / \mathrm{L}$.

Morison found that the error arose in steep waves mainly' due to the crest pressure being attenuated more than the trough. This points 
s'amplifiait dans le cas des houles cambrées, c'était surtout parce que la pression à la crête était plus fortement atténuée qu'au creux, ce qui semble indiquer qu'à côté des forces purement hydrodynamiques, des forces d'inertie doivent également être prises en considération. Les instruments ne devraient donc pas être étalonnés uniquement en pression statique, mais soumis aussi à des fluctuations de pression pour s'assurer qu'ils sont sensibles aux brusques variations produites par la crête d'une houle cambrée.

Donn [11] qui prévoyait, d'après la méthode Sverdrup-Munk, une houle de 18,5 pieds $(5,64 \mathrm{~m})$ d'amplitude et 6,5 secondes de période, a été surpris d'enregistrer une houle de 9,5 pieds $(2,89 \mathrm{~m})$ seulement. Il en déduisit que « la méthode de prévision Sverdrup-Munk semble inapplicable aux tempêtes caractérisées par une grande vitesse du vent et un «fetch 》limité 》. En réalité, l'erreur a pu provenir de ce que l'instrument n'était pas adapté à l'enregistrement des houles courtes et cambrées qu'on pouvait prévoir en pareil cas.

Une autre erreur pouvant se produire en eau peu profonde est une fluctuation de la pression par l'effet Bernoulli, des courants horizontaux alternatifs contournant l'instrument. Si l' « orifice » dé la hauteur piézométrique est tourné du côté d'où la houle arrive, la pression dynamique sera enregistrée et viendra s'ajouter à la variation due au passage de la houle. S'il est tourné vers la côte, une pression dynamique négative coïncidera avec le passage de la crête et une pression positive avec le passage du creux; il en résultera une réduction de la fluctuation réelle de la pression. Dans le premier cas, la houle enregistrée sera trop forte, dans le second trop faible. Quand l'orifice se trouve au sommet de l'instrument, la tendance à la dépression (réduisant aussi bien la hauteur des crêtes que celle des creux) dépendra de la courbure de la face considérée. C'est certainement la position la meilleure à lui donner; l'on devra rendre la surface supérieure plate, pour écarter de «l'orifice» les perturbations, l'enregistreur étant en dessous et faisant partie d'une grande sphère.

\section{Réfraction de la houle.}

Quand plusieurs trains d'ondes approchent de la côte suivant une même direction oblique, leur réfraction apparaîtra à des profondeurs différentes selon leur période. Cette divergence de direction continuera jusqu'à ce qu'ils aient atteint des eaux très peu profondes; à partir de ce moment, la réfraction sera la même pour toutes les ondes, puisque la vitesse ne dépend que de la profondeur. Fuchs [16] a noté que la divergence maximum se manifeste aux points où se trouvent to the fact that inertia forces must be considered as well as purely hydrodynamic forces. Instruments should not be calibrated by static pressure alone but should be tested with fluctuating pressures to prove that they can respond to the swift changes efrected by a steep wave crest.

Donn [11], who had forecast a wave of height 18.5 feet and period 6.5 seconds by the SverdrupMunk method was surprised when he recorded only a 9.5 feet wave. He concluded that "The forecast theory" of Sverdrup-Munk appears inapplicable to storms in which the velocity of the winds is high and the fetch is short"; whereas, in fact, the fault may have been in the inability of the instrument to record the short steep waves to be expected under these circumstances.

Another error likely to occur with waves in shallow water is the fluctuating pressure due to the Bernoulli effect when horizontally oscillating water is diverted around the instrument. Should the "orifice" of the pressure head be located on a side facing the direction of approach of the waves the dynamic pressure of the water will be recorded and added to the fluctuation due to the wave motion. When it is oriented shorewards a negative dynamic pressure coincides with the passage of the crest overhead and a positive value with the trough, thus reducing the normal pressure fluctuation. The former case results in the recorded wave being too large and the latter case to small. When the "orifice" is at the top of the recorder the tendency for "lift" (which reduces both crest and trough heights) depends upon the curvature on that face. This is certainly the best position for it and, in order to force disturbances away from the "orifice", the top surface should be flat with the recorder making up part of a large sphere below it.

\section{Wave Refraction.}

When several wave trains approach the coast from the same oblique direction they will commence refracting at different depths, as determined by their periods. This divergence in direction continues until they reach very shallow water when further refraction is the same for all waves because their velocity depends only upon the depth. As noted by Fuchs [16] the maximum divergence takes place at depths in which pressure recorders are commonly located. This is illustrated in figure 4, which shows the divergence between 7 and 10 second waves and between 10 and 13 second waves for the initial conditions as detailed.

Pierson $[30]$ has observed that waves of different periods emanating from different directions could reach the shore travelling in the same direction. Longuet-Higgins [27] has treat- 


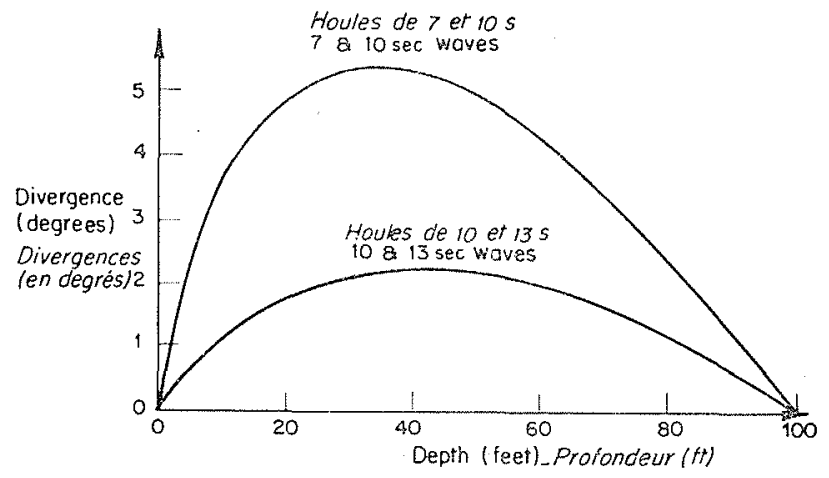

Frg. 4. - Diagramme montrant, pour diverses prolondeurs, les divergences entre houles de $7 \mathrm{~s}$ et de $10 \mathrm{~s}$ et entre houles de $10 \mathrm{~s}$ et de $13 \mathrm{~s}$, l'augle d'incidence étant de $45^{\circ}$ pour loutes les houles, a une profondeur de $30 \mathrm{~m}$.

Graph of wave divergence at various depths between 7 and 10 second waves and between 10 and 13 second waves where the angle of incidence is $45^{\circ}$ for all waves at a depth of 100 feet.

d'ordinaire placés les enregistreurs de pression. C'est ce qu'on voit sur la figure 4 , qui montre la divergence entre ondes à périodes de 7 et de 10 secondes et entre celles de 10 et 13 secondes, dans des conditions initiales données.

Pierson [30] a noté que des vagues de périodes différentes, issues de directions différentes, pourraient atteindre la côte suivant une même direction. Longuet-Higgins [27] a traité le problème dans l'hypothèse d'une mer complexe et a montré qu'une interférence de ce senre se traduit par des crêtes longues à l'approche du rivage. Il montre aussi comment le phénomène de réfraction atténue le raidissement dù à la réduction de profondeur et comment les houles longues peuvent être rendues plus cambrées que des houles courtes ayant subi une réfraction en ligne avec elles.

Les crêtes courtes qui existent toujours dans la houle océaniçue et qui peuvent être accentuées au cours de la sélection suivant le processus de réfraction, risquent d'avoir des répercussions sur les variations de la pression sous la surface libre; lampleur de cette action nous échappe encore.

On peut procéder au calcul de la réduction de la cambrure lorsque les vagues se réfractent et que leur énergie s'étend sur une plus grande longueur de crête. Les coefficients de réfraction peuvent être calculés pour chacune des périodes données; on aurait ainsi une idée des caractéristiques de la houle en eau profonde. Bien entendu, cela présuppose la connaissance de la direction initiale des ondes; des erreurs peuvent s'y glisser si les données que l'on possède à ce sujet sont inexactes, comme l'a noté Chinn [8].

Une erreur liée à l'implantation de l'appareil peut surgir de ce que l'on omet une partie ed this problem assuming a complex sea and has shown that such interference makes for long crestedness near the beach. He also illustrates how refraction reduces the steepening due to the shoaling water and how long waves can be steepened more than short waves which have been refracted into line with them.

The short crestedness which is always present in ocean waves and which can be exaggerated during the selective refraction process, may have some effect on the sub-surface pressure fluctuation. The extent of this is still unknown.

A possible calculation is the reduction in wave steepening as waves are refracted and energy is spread along a greater length of crest. Refraction coefficients can be computed for any given wave period and this gives some idea of the deep water wave characteristics. Of course, this presupposes that the original wave directions are lnown and, as Chinn [8] noted, error's can be introduced when this information is not accurate.

An error due to instrument location can arise from the complete ommission of some part of the wave spectrum. For example, Barber [3] has shown the path of waves (up to 18 seconds) approaching, a recording site at Perranporth, Cornwall (see figure 5) from a south-west direction. It can be shown that 6 second waves would continue straight past the site. Waves of other periods would be refracted by differing amounts

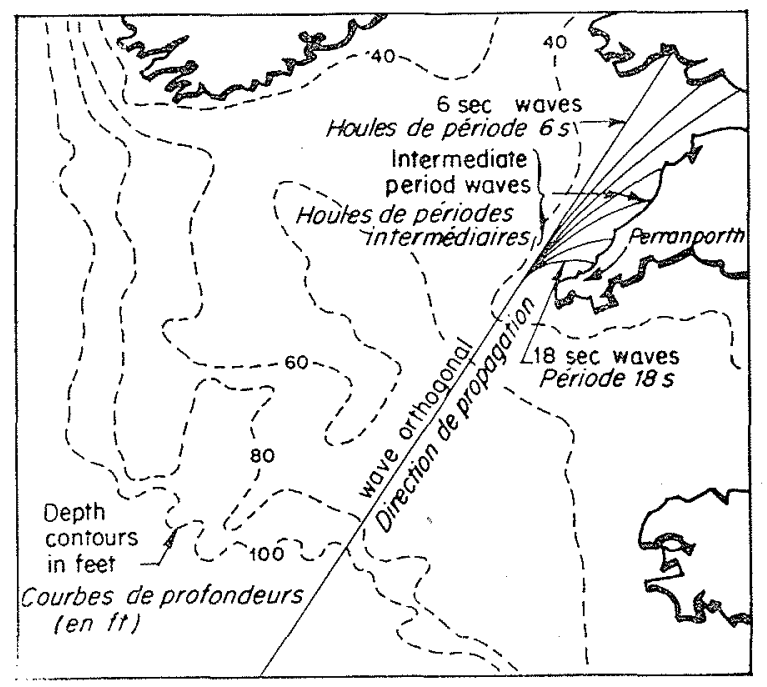

Fic. 5. -.. Propagation d'un train d'ondes de $18 \mathrm{~s}$ (d'après référence 3) an voisinage d'une station d'enregistrement a Perramport (Angleterre). On voit également la propagation des houles de $6 \mathrm{~s}$ du spectre et les directions de propagation probables des autres trains intermédiaires.

Path of 18 sec. wave train (from Reference 3) approaching a recorder station at Perranport, England. Also shown is the path of the 6 second waves in the spectrum and the probable orthogonals of other intermediate wave trains. 
du spectre. C'est ainsi que Barber [3] a montré le mode de progression de la houle (jusqu'à 18 secondes de période) vers une station d'enregistrement à Perranporth (Cornwall) (fig. 4) à partir d'une direction sud-ouest. On voit que les houles de 6 secondes conservent leur axe de progression au-delà de ce point, tandis que les houles de période différente sont plus ou moins réfractées et atteignent la côte plus ou moins loin vers le nord-onest.

Cette possibilité d'amortissement des ondes les plus longues qui atteignent finalement l'enregistreur dans de telles conditions, après avoir croisé le réseau des houles courtes, n'a pas encore été étudiée. Une partie de la houle de période courte peut parvenir à l'appareil dans un cas semblable du fait d'une dispersion latérale, comme dans le cas de la diffraction, mais il serait extrêmement malaisé d'en tenir compte dans l'estimation des caractéristiques de la houle en eau profonde.

Nous n'envisageons pas la diffraction en ellemême comme une source d'erreur dans l'enregistrement, car on n'imagine pas que les enregistreurs destinés à relever les caractéristiques de la houle au large puissent être placés « à l'ombre »d'un obstacle quelconque, naturel ou artificiel, bien que cela ait déjà été fait [11].

\section{Ondes stationnaires.}

Les ondes stationnaires se forment à la rencontre de deux trains d'ondes d'égale période. Cela peut arriver soit au voisinage d'une île, où les vagues subissent la réfraction et la diffraction sur les deux côtes et se croisent ensuite sur la côte « sous le vent » de l'île, soit au large d'une surface réfléchissante, par exemple d'un ouvrage construit par l'homme (brise-lames, digue, etc.), d'une falaise, voire même d'une plage.

On peut facilement éviter le premier de ces cas, tandis que le second peut très bien se présenter, de façon plus ou moins accusée, comme l'a fait remarquer Pierson [30]. En pareil cas, l'enregistreur notera non seulement l'onde incidente, mais aussi l'onde réfléchie et une variation de pression de fréquence double de celle de la houle primitive, pouvant provoquer des microséismes si cela se produit par une vaste étendue [25].

Le coefficient de réflexion de divers obstacles a été obtenu expérimentalement $[9,18,19,21]$ et on a constaté qu'il variait avec la cambrure de la houle, la pente du rivage et sa rugosité. La période ne s'est pas révélée comme un paramètre ayant une influence notable sur ce coefficient [19]. Comme il n'y a pas lieu de supposer qu'un enregistreur puisse être placé au large d'un obstacle particulièrement réfléchissant, tel and would reach the shore at various distances to the north-west.

The possibility of attenuation of the longer waves which ultimately reach the recorder under such circumstances, having crossed the path of the short waves, has not been studied to date. Some of the short period swell may arrive at the recorder in the above case due to lateral spreading as in wave diffraction, but allowance for it in deep water wave characteristics would be extremely difficult.

Diffraction itself is not discussed as a source of error in wave recording since it is assumed that recorders, purpoting to record wave conditions in the open sea, would not be placed in the "shadow" of any obstructions either natural or man made, although this has been done [11].

\section{Standing Waves.}

Standing waves are formed when two opposing wave trains of equal period meet. This can occur ( $a$ ) near an island where waves are refracted and diffracted either side and meet leeward of the island, or $(b)$ offshore from a reflecting surface such as a man made structure (breakwater, sea wall, etc.), a cliff or even a beach.

Case (a) can easily be avoided, but, as Pierson [30] has noted, case $(b)$ is likely to arise with varying degrees of intensity. The resultant effect is that the recorder not only records the incident wave but also the reflected wave and a pressure fluctuation of twice the frequency of the original wave which can cause microseismic pulses when occuring over a wide area [25].

The coefficient of reflection for various surfaces has been obtained from experiment [9, 18, $19,21]$ and has been found to vary with wave steepness, beach slope und beach roughness. Wave period as a parameter was not found to influence the coefficient greatly [19]. As it is not expected that a recorder would be placed offshore from a good reflector such as a cliff or a sea wall, with slopes ranging from $20^{\circ}$ to $90^{\circ}$ to the horizontal, only beach slopes will be considered. Hoyle and King [20] have measured many such slopes and three types might be considered typical, namely :

Pebbles $1 / 4^{\prime \prime}$ to $11 / 2^{\prime \prime}$, slope $=1 / 5$;

Mixed sand and 1/4" pebbles, slope $=1 / 10$;

Medium to fine sands, slope $=1 / 25$.

Reflection coefficients for such slopes have been taken from the graphs of Greslou and Mahé [18] and reproduced in figure 6 . It is clearly visible that low long swell is more sub- 
qu'une falaise ou une digue inclinée de $20^{\circ}$ à $90^{\circ}$ sur l'horizontale, on ne considérera ici que le cas des plages. Hoyle et King [20] ont mesuré leur pente dans plusieur's cas, qu'on peut ranger dans trois catégories typiques :

Galets $1 / 4^{\prime \prime}$ à $1^{1 / 2 \prime \prime}(6,3$ à $38 \mathrm{~mm})$; pente $=1 / 5$. Mélange de sable et de galets $1 / 4^{\prime \prime}(6,3 \mathrm{~mm})$; pente $1 / 10$.

Sable, moyen à fin; pente $1 / 25$.

Nous avons relevé les coefficients de réflexion pour des pentes de ce genre sur les graphiques établis par Greslou et Mahé [18] et reproduits sur la figure 6 . Il apparaît clairement qu'une houle longue et plate se réfléchit davantage qu'une houle cambrée et que le rivage le plus abrupt est aussi le meilleur réflecteur. Bien entendu, les effets de frottement et d'infiltration abaisseraient probablement les chiffres déduits de la figure 6, laquelle a été obtenue sur une surface plane et lisse, imperméable.

II y a lieu de noter que c'est la houle longue et plate qui crée les plages les plus raides, pour une granulométrie donnée; elle favorise ainsi sa propre réflexion. Au contraire, les houles cambrées tendent à aplatir le profil de la plage, à créer au large une barre, à briser par conséquent les vagues successivès el à dissiper leur énergie avant qu'elles soient réfléchies. On trouvera sur la figure 6 , comme cambrure critique, la valeur 0,025, obtenue par Johnson [23].

Dans le cas idéal d'un train d'ondes isolé abordant la côte et subissant une réflexion, un appareil enregistreur placé à une distance égale à un multiple quelconque des demi-longueurs d'onde (comme $A, A^{\prime}$, sur la figure 7 ) recueillera la pression réelle due à l'onde stationnaire. S'il est placé sur un nœud tel que $B$, il ne mesurera point de pression. En d'autres positions, il indiquera une fraction variable de l'amplitude de cette houle.

S'il y a plusieurs trains de houle et si l'enregistreur est placé à une certaine distance, invariable, à partir de la surface réfléchissante, il

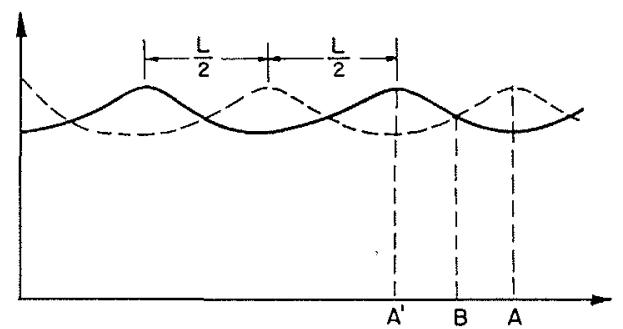

Fig. 7. - Train de houle régulier simple, réfléchi par une surface verticale. On distingue les points où auront lieu les fluctuations maximum et minimum de lá pression.

A single regular wave train being reflected from a vertical surface showing the locations where maximum and minimum pressure fluctuations will occur.

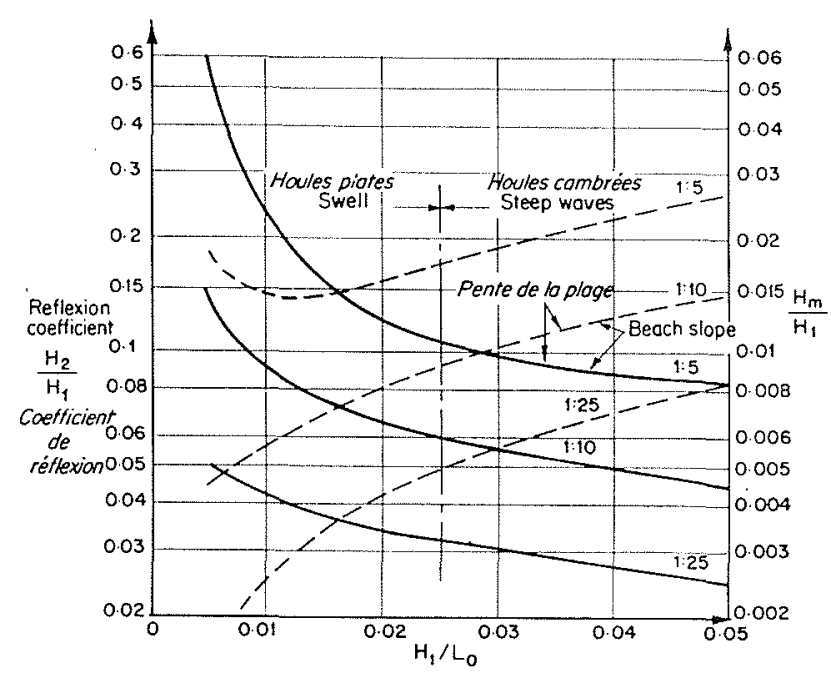

FIG. 6. - Diagramme montrant les coefficients de réflexion (d'après la référence 18 ) et les rapports entre les fluctuations de pression a fréquence double et les fluctuations de la houle incidente $H_{1}$ pour diverses valeurs de $\mathrm{H}_{\mathrm{t}} / \mathrm{L}_{\mathrm{O}}$.

Graph showing reflection coefficient (from Reference 18) and ratios of double frequency pressure fuctuations to those of the incident wave $\mathrm{H}_{\mathrm{L}}$ for various values of

$$
\mathrm{H}_{1} / \mathrm{L}_{0} \text {. }
$$

ject to reflection than steeper waves and that the steeper beach is the better reflector. Of course, friction and percolation are likely to reduce the figures obtained from figure 6 which were obtained from a smooth impervious plain surface.

It is to be noted that long low swell creates the steepest possible beach for any given sediment size and so aids in its own reflection. Steep waves on the other hand tend to flatten the beach profile, cause an offshore bar and so break the waves and dissipate them before they have an opportunity of being reflected. The critical steepness as determined by Johnson [23] of 0.025 is marked in figure 6 .

Dealing with an ideal situation where a single train of waves approaches the coast and is reflected, a recorder placed at any multiple of the half wave lengths ( $A, A^{1}$ in figure 7) will record the actual pressure due to the standing wave. If it is placed at a nodal point such as $B$ no pressure fluctuation will be measured at all. Other positions will give varying fractions of the standing wave amplitude.

In the case of several wave trains being present the fixed distance of the recorder from the reflecting surface will cause it to select certain wave periods in recording such standing waves. For other wave periods it will be at the 
enregistrera de préférence certaines périodes. Pour d'autres périodes, il se trouvera au point nodal et ne décélera même pas l'onde incidente. On pourra réduire notablement lerreur en placant l'instrument à quelques longueurs d'onde au large, en des points où l'on a des chances de trouver des réflexions provenant de plusieurs directions et où l'amplitude de la houle réfléchie est atténuée du fait que cette houle se propage dans des eaux plus profondes. Il n'y a qu'un cas où cette erreur se révélera importante, c'est celui de l'arrivée d'une houle à longue période, annonciatrice d'une tempête.

La seconde erreur que peuvent causer les ondes stationnaires est la fluctuation à fréquence double de la pression sur le fond dans toute la zone des interférences. Cooper et Longuet-Higgins [9] l'ont évaluée au cours d'une étude sur modèle et le second [25] a montré que cette pression ne s'amortit pas avec la profondeur, comme c'est le cas des fluetuations au voisinage de la surface pour une houle progressive. Selon lui, cette fluctuation du second ordre a comme valeur :

$$
\mathbf{H}_{m}=\frac{4 \pi^{2} \mathbf{H}_{1} \mathbf{H}_{2}}{g^{\top} \top^{2}}
$$

$\mathrm{H}_{1}$ et $\mathrm{H}_{2}$ étant les amplitudes des houles opposées, c'est-à-dire de l'incidente et de la réfléchie, et $\mathbf{T}$, la période. $\mathrm{H}_{m}$ se réduit à :

$$
\mathrm{H}_{m}=2 \pi\left(\mathrm{H}_{1} / \mathrm{L}_{0}\right) \mathrm{H}_{2}=2 \pi\left(\mathrm{H}_{1} / \mathrm{L}_{0}\right) r \mathrm{H}_{1}
$$

où $\mathrm{L}_{0}$ est la longueur d'onde en eau profonde et $r$ le coefficient de réflexion. Sur la figure 6 a été porté le rapport $\mathrm{H}_{m} / \mathrm{H}_{1}$, pour différentes valeurs de $\mathrm{H}_{1} / \mathrm{L}_{0}$ et de la pente du rivage. La valeur de $\mathrm{H}_{m}$ représente une fluctuation de la pression au fond devant normalement se trouver amplifiée par le facteur de réponse à la pression, pour donner l'oscillation de surface. Si, par exemple, l'enregistreur se trouve à une profondeur telle que $d / L=0,125$ (voir ch. 8), le facteur de réponse pour la fluctuation du second ordre serait de l'ordre de 2,5. Même alors, on pourrait évidemment négliger cette bande d'ondes dans la lecture de l'enregistrement.

Le phénomène de «surf beat » [44], causé par le déferlement périodique, sur la plage, d'une succession de vagues de grande amplitude, ne pourrait pas figurer dans un graphique reliant le vent à la houle, en raison de sa période, trop longue, de 60 secondes et plus [27].

\section{Analyse harmonique.}

L'analyseur de fréquences décomposant un enregistrement de houle en ses composants présuppose leur caractère sinusoïdal. Mais en mer nodal point and would not record even the incident wave. A method of reducing the error substantially is to locate the instrument some wave lengths offshore where reflections from several points are likely to occur and where the amplitude of the reflected wave is attenuated as it propagates into the greater depths. The only time this error can assume importance is when the long period swell arrives heralding the arrival of a storm.

The second error that can arise due to standing waves is the domble frequency pressure fluctuation on the ocean bed which is spread uniformly" over the whole area of wave interference. Cooper and Longuet-Higgins [9] have measured it in a model study and LonguetHiggins [25] as shown that this pressure is not attenuated with depth as is the sub-surface fluctuation from a progressive wave system. He has shown the magnitude of this second order fluctuation to be :

$$
\mathrm{H}_{m}=\frac{4 \pi^{2} \mathrm{H}_{1} \mathrm{H}_{2}}{g \mathrm{~T}^{2}}
$$

where $H_{1}$ and $H_{2}$ are the amplitudes of the opposing waves i.e. incident and reflected waves, and $\mathrm{T}$ is the wave period,

which reduces to :

$$
\mathrm{H}_{m}=2 \pi\left(\mathrm{H}_{1} / \mathrm{L}_{0}\right) \mathrm{H}_{2}=2 \pi\left(\mathrm{H}_{1} / \mathrm{L}_{0}\right) r \mathrm{H}_{1}
$$

where $L_{0}$ is the deep water wave length and $r$ the reflection coefficient. The ratio of $\mathrm{H}_{m} / \mathrm{H}_{1}$ has been graphed in figure 6 for various values of $\mathrm{H}_{1} / \mathrm{L}_{0}$, and beach slope.

The value of $\mathrm{H}_{m}$ is a bottom pressure fluctualion which under normal circumstances would be amplified by the pressure response factor to give an apparent surface oscillation. Assuming the recorder is placed in a depth where $d / L=0.125$ (see Section 8) then the response factor for the second order fluctuation is of the order of 2.5. Even so it is obvious that this band of waves can usually be isnored when reading the analysis.

The phenomenon of surf beat [44], which is caused by the periodic breaking of a series of high waves on the beach, is not likely to enter a wind-wave record due to its long period of 60 seconds or more [30].

\section{Wave Analysis.}

The frequency analyser which divides a wave record into its component wave trains assumes that these are sinusoidal. In the sea, however, a simple wave train departs significantly from a sinusoidal profile, as when it is steepened. The 
le train d'ondes le plus simple s'écarte de facon appréciable du profil sinusoïdal, par exemple quand il tend à se cambrer. L'analyseur décompose cel enregistrement en un certain nombre de trains d'ondes sinusoïdales ou harmoniques, dont le premier a la période même de la houle réelle, et le second, une période moitié moindre. Il peut y" avoir d'autres harmoniques encore, mais, d'ordinaire, ils sont négligeables.

Heureusement, les enregistreurs de houle a variation de pression ont tendance à éliminer les pointes aiguës dans l'oscillation de la surface; ils livrent done un profil sensiblement sinusoïdal. Néanmoins, si la houle devient très cambrée, des harmoniques sont introduits par l'analyse et il apparait une bande parasite, de fréquence double de l'ondulation primitive.

Barber et Ursell [4] ont montré qu'entre l'amplitude du $2^{\circ}$ harmonique et l'amplitude de l'onde primitive existe le rapport:

$$
\frac{\mathrm{H}_{2}}{\mathrm{H}_{1}} \leqslant\left\lceil\frac{3 \cosh (4 \pi d / \mathrm{L})}{4[\cosh (4 \pi d / \mathrm{L})-1]} \operatorname{sech} \frac{2 \pi d}{\mathrm{~L}}\right\rceil \frac{\mathrm{H}_{1}}{d}
$$

$\mathrm{H}_{1}$ étant l'amplitude de l'onde enregistrée à une profondeur d pour une longueur d'onde L.

Si l'on applique à cette expression le facteur de réponse «pression » approprié, de facon à obtenir la fluctuation équivalente en surface, on a :

amplitude du $2^{\circ}$ hamonigne en surface amplitude fondamentale en surface

$$
\begin{aligned}
\leqslant[] \frac{\mathrm{H}_{1}}{d} & \frac{\cosh (2 \pi d / k \mathrm{~L})}{\cosh (2 \pi d / \mathrm{L})} \\
& =\lceil\rceil \frac{\mathrm{H}_{s}}{d} \frac{\cosh (2 \pi d / k \mathrm{~L})}{\cosh (2 \pi d / \mathrm{L})^{2}}=y \frac{\mathrm{H}_{s}}{d}
\end{aligned}
$$

$k$ étant une fraction déterminée par le fait que la longueur d'onde de l'harmonique en profondeur infinie (proportionnelle an carré de la période) est égale au cuart de la longueur d'onde initiale; et $\mathrm{H}_{s}$ est l'amplitude de l'onde de surface.

Sur la figure 8 , nous avons porté les valeurs de $y$ en fonction de $d / \mathrm{L}$; on voit qu'un minimum correspond à $d / L=0,125$, la houle s'amplifiant rapidement de part et d'autre de ce point. Pour $d / L>0,125$, cet accroissement est dû aux fortes valeurs que prend le facteur de réponse de la pression (les valeurs $>2,0$ ne sont guère utilisées); quand $d / \mathbf{L}<0,125$, il est dû à la cambrure de la houle.

Sur la figure 9, nous avons tracé les courbes d'égale valeur de $y$ sur un graphique pareil à celui de la figure 3 ; on peut en déduire la profondeur la plus favorable à Ia réduction des harmoniques pour la bande des périodes devant être enregistrées. On voit que pour des houles de période de 7 à 14 secondes, cette profondeur est analyser interprets such a record as several sinusoidal wave trains, or harmonics, the first having the same period as the true wave form and a second having half this period. There possibly may be more than these but they are generally negligible.

Fortunately the tendeney is for pressure wave recorders to omit any steep peaks of the surface oscillation and so produce a profile nearly sinusoidal. But, where waves become very steep, harmonics are produced in the analysis and a spurious band of unrecolded waves appears at double the frequency of the original undulation.

Barbe: and Ursell [4? have shown that the

$$
\frac{\text { amplitude of } 2 \text { nd harmonic }}{\text { amplitude of original wave }}
$$

$=\frac{\mathrm{H}_{2}}{\mathrm{H}_{1}} \leqslant\left\lceil\frac{3 \cosh (4 \pi d / \mathrm{L})}{4[\cosh (4 \pi d / L)-1]} \operatorname{sech} \frac{2 \pi d}{\mathrm{~L}}\right\rceil \frac{\mathrm{H}_{1}}{d}$

where $H_{1}$ is the wave amplitude recorded at a depth $d$ for a wave of length $L$.

Applying the appropriate pressure response factors in order to obtain the equivalent surface lluctuation, we have

$$
\begin{gathered}
\frac{\text { 2nd harmonic surface amplitude }}{\text { original surface amplitude }} \\
\leqslant[] \frac{\mathrm{H}_{1}}{d} \frac{\cosh (2 \pi d / k \mathrm{~L})}{\cosh (2 \pi d / \mathrm{L})} \\
=\left[\square \frac{\mathrm{H}_{s}}{d} \frac{\cosh (2 \pi d / k \mathrm{~L})}{\cosh (2 \pi d / \mathrm{L})^{2}}=\eta \frac{\mathrm{H}_{s}}{d}\right.
\end{gathered}
$$

where $k$ is a fraction determined by the fact that the deep-water wave length of the harmonic (proportional to the square of the period) is one quarter of the original wave length, and $H_{s}$ is the amplitude of the surface wave.

Values of $y$ have been plotted against values of $d / L$ in figure 8 where it is seen that a minimum value occurs at $d / L=0.125$ with the wave rising steeply on either side. Where $d / L>0.125$ the increase is due to large values of the pressure response factor (usually those $>2.0$ are not used); and where $d / \mathrm{L}<0.125$ the increase is due to the wave steepness.

In figure 9 isopleths of $y$ are drawn on a similar chart to figure 3 from which the best depth for minimising harmonics can be ascertained for the band of periods likely to be recorded. It can be seen that for waves of 7 to 14 second period the best depth is 50 feet and the optimum point is at 10.5 seconds. 


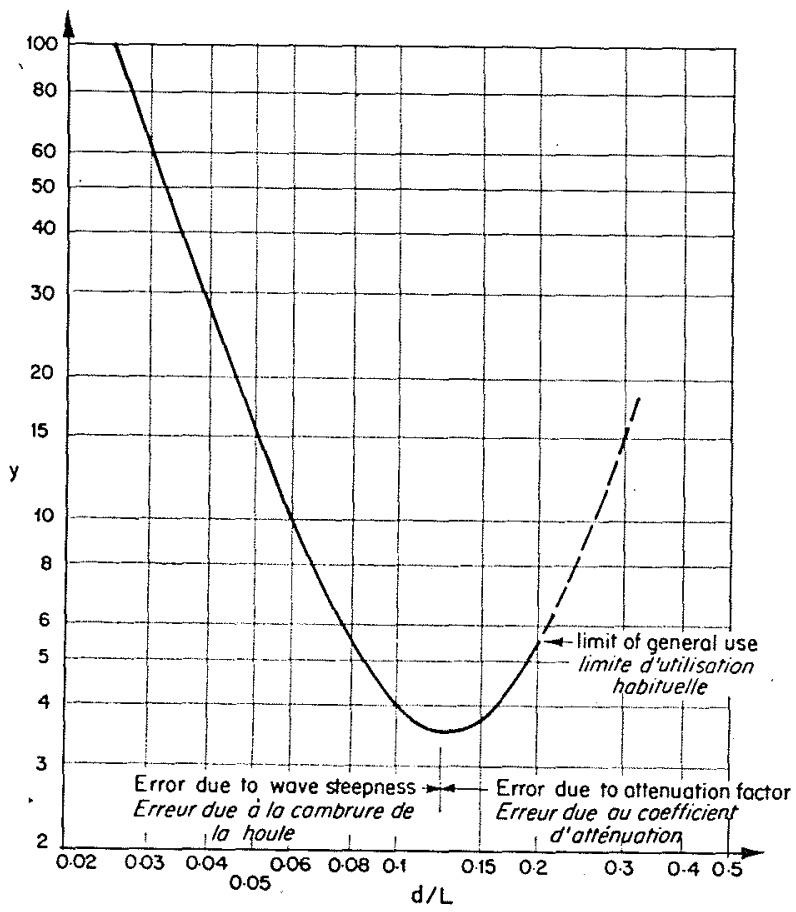

Fig. 8. - Diagramme des valeurs de $y$ pour différents $d / L$ (voir le texte).

Graph showing values of $\mathrm{y}$ for various values of $d / \mathrm{L}$ (see text).

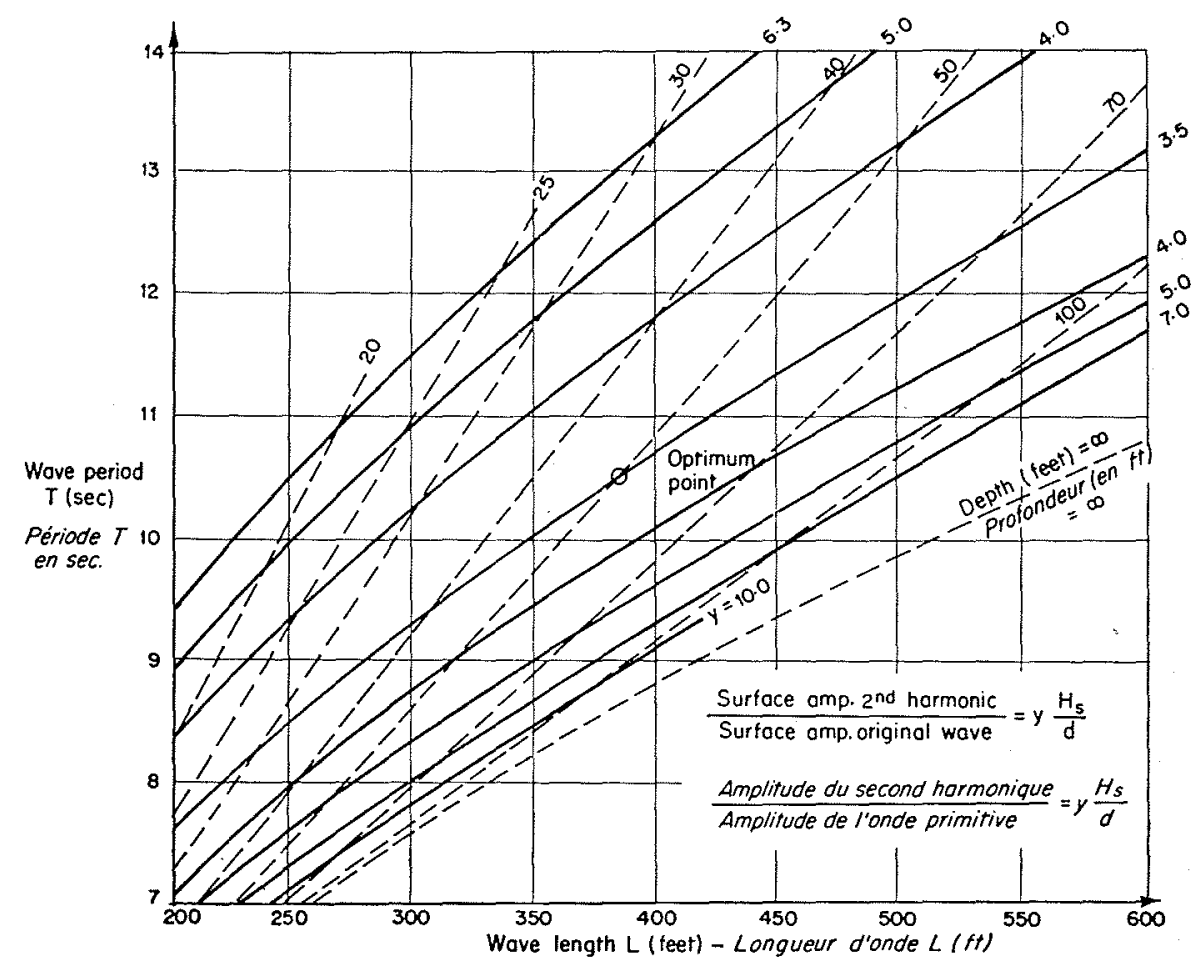

Fig. 9. - Valeurs de $y$ dont on peut tirer le rapport

entre l'amplitude du second harmonique et l'amplitude de l'onde primitive $\left[=y\left(\mathrm{H}_{s} / d\right)\right\rceil$ en fonction des mêmes paramètres que ceux de la figure 3.

Values of y from which the ratio of the amplitudes of the second harmonic to the original wave are obtainable $\left[=y\left(H_{s} / d\right)\right]$ graphed against similar parameters to those of figure 3 . 
de 50 pieds $(15 \mathrm{~m})$, le point optimum étant à 10,5 secondes.

Il y a lieu de noter que les expressions cidessus concernent un train de vagues régulier et isolé et de se rappeler la conclusion tirée par Barber et Ursell [4] : « La houle qu'on observe sur une côte ne constitue pas ordinairement un train d'ondes régulier, car plusieurs périodes sont présentes en même temps. Il n'existe pas de théorie applicable à une houle complexe; nous pensons toutefois que la théorie présentée ci-dessus donnera, dans une certaine mesure, l'ordre de grandeur des harmoniques supérieurs de tout train d'ondes composant. »

L'appareil analyseur examiné par Barber et Ursell a été décrit par Tucker [45], qui indique qu'on peut s'attendre, pour chaque enregistrement, à une précision relative de $3 \%$ dans l'estimation de la hauteur des vagues et à une exactitude de $7 \%$ dans la comparaison d'une série d'enregistrements. Ces erreurs ne sont pas à attribuer à la présence d'harmoniques, mais aux cellules photoélectriques employées, influencées par la blancheur de l'enregistrement et admettant de lentes sorties d'alignement.

Un autre appareil analyseur, décrit par Piersont et Chang [31], a été étudié par Pierson [30], surtout du point de vue de l'amortissement de certaines bandes du spectre, dû̀ à l'emploi de filtres spéciaux.

\section{Longueur de l'enregistrement.}

Un enregistrement continu peut sembler idéal pour donner une vue d'ensemble de la houle émanant d'un centre de tempête; toutefois, il se présente quelques difficultés, sans parler des frais, qui font écarter une telle réalisation. On reconnaîtra facilement que l'analyse devra porter sur des bandes d'enregistrement de longueur finie, ni trop' longues, ni trop courtes, ni trop distantes les unes des autres.

Quand une houle d'une certaine période dépasse une houle de période légèrement plus courte, elle produit une zone d'interférences se modifiant continuellement au fur et à mesure que la crête de la houle la plus longue passe d'une des crêtes de période plus courte à la suivante; la même configuration se répète. Pour enregistrer toutes les phases de ce processus, il faut que l'enregistrement s'étende sur une longueur suffisante. Ainsi, pour qu'une onde de onze secondes présente un décalage d'une période, relativement à une onde de dix secondes, il faut 100 secondes ( $\mathrm{T}^{2}$ ); donc si 15 répétitions sont nécessaires à une analyse convenable, l'enregistrement devra durer 25 minutes. Pour des trains d'onde de 7 et 8 secondes, il n'exigerait que la moitié de ce temps.
It should be noted that the above expressions refer to a single regular train of waves and it is well to record Barber and Ursell's concluding remark [4]: "The swell observed on the coast is not in general a regular train of waves, and many periodicities are present at the same time. There is no theory for a complex wave pattern, but it is expected that the theory discussed above will give at any rate the order of magnitude of the higher harmonics of each constituent wave train."

The analyser discussed by Barber and Ursell has been described by Tucker [45] where he states that for any one record a comparative accuracy of $3 \%$ in wave heights can be expected and in the comparison of successive records an accuracy of the order of $7 \%$ is obtainable. These errors do not refer to the presence of harmonics but are introduced through the photoelectric cells used, which are affected by the whiteness of the records and are subject to slow mal-alignment.

Another analyser, described by Pierson and Chang [31], is discussed by Pierson [30] particularly with respect to the loss of sharpness in the spectrum by the use of particular filters.

\section{Length of Record.}

Although a continuous record may sound ideal for giving a complete picture of the waves emanating from a storm centre, economics apart, there are several difficulties which preclude such a step. It is readily appreciated that finite lengths of record must be analysed. They should not be too long, too short, or be spaced too far from the adjacent records.

When a wave of one period is passing another of a slightly smaller period it causes an interference pattern which changes continuously' whilst the crest moves from one crest of the smaller period wave to the next and the pattern then repeats itself. In order to record all combinations of the pattern a sufficient length of record must be taken. For example, the time taken by an eleven second wave to get out of step by one wave period with a ten second wave is 100 seconds $\left(\mathrm{T}^{2}\right)$, therefore, if 15 repetitions are required for it to be adequately analysed, the record must be of 25 minutes duration. A similar record for 7 and 8 second wave trains need be only half this length.

A record cannot be of such a length that the band of periods changes substantially during the 
D'autre part, lenregistrement ne devia pas avoir une durće telle que la gamme des périodes ait le temps de changer de facon appréciable, car l'analyse serait brouillée. La rapidité de ce changement dépendra de la proximité de l'enregistreur à la zone génératrice de la houle. Sur une longue distance, les différents groupes de vagues ont le temps de se séparer les uns des autres, le changement sera lent et autorisera un enregistrement de longue durée, très souhaitable en pareil cas, comme on l'a vu ci-dessus. La variation des périodes à l'intérieur du « fetch», par contre, est plus rapide, et impose un enregistrement plus bref, tout à fait suffisant d'ailleurs, comme il a été dit au paragraphe précédent.

Barber et Ursell [4] ont étudié le problème indépendamment de la question de la période; ils suggèrent que pour des houles ayant parcouru de 1000 à 2000 miles, la longueur d'enregistrement optimum soit de 33 et 47 minutes respectivement. Si la houle est d'origine plus proche, la longueur optima proposée est de 17 minutes.

Tukey [47], Deacon [10] citant Tucker, et Tucker [46] ont examiné le problème de la durée de l'enregistrement, en tenant comple du caractère aléatoire des amplitudes de la houle; ils ont montré que l'écart-type d'une analyse harmonique est d'autant plus faible que l'enregistrement est plus long, et que l'erreur relative est d'autant plus grande que le spectre est plus étroit. Deacon $[10]$ a résumé la question en disant : "Si le spectre de la houle est étroit, les amplitudes moyennes, évaluées sur des enregistrements de 10 minutes, peuvent facilement différer entre elles de $25 \%$. L'erreur probable devient d'autant plus faible que le spectre est plus large. Cela veut dire qu'un enregistrement de 10 minutes ne peut pas renseigner de façon absolument sûre sur ce qui se passera au cours des 10 minutes suivantes, ni sur ce qui se passe, en même temps, à un mile de là. » $\mathrm{Ce}$ n'est vrai, naturellement, que pour des enregistrements successifs de 10 minutes. En fait, et de ce point de vue, un enregistrement de 20 minutes suffit amplement aux besoins de la pratique.

En ce qui concerne l'espacement entre enregistrements, il dépend du degré de précision avec lequel on désire connaitre la succession de vagues issue d'une zone génératrice. Même si les enregistrements sont destinés à établir des formules permettant la prévision de la houle, l'espacement le plus convenable est de deux heures, bien que Barber et. Ursell [4] aient indiqué qu'il conviendrait - pour des raisons de déphasage perturbateur et de modifications notables de la hande de fréquence -., de procéder à l'analyse par tranches successives de l'enregistrement. length of the record, otherwise the analysis will suffer from blurring. This rate of change will vary with the proximity of the wave recorder to the storm centre generating the waves. In a long decay distance the wave groups have time to separate and the rate of change will be slow permitting a longer record, which, as shown above, is very necessary under such circumstances. On the other hand, the rate of change of periods within the feich is more rapid, dictating a small record, which in any case is quite adequate as shown in the previous paragraph.

Barber and Ursell [4] have analysed this problem out of consideration of the wave period resolution and suggest that for storms 1000 to 2000 miles away the optimum length of record is 33 and 47 minutes respectively. For a close storm the optimum length suggested is $17 \mathrm{mi}$ nutes.

Tukey [47], Deacon [10] citing Tucker, and Tucker [46] have discussed the length of the record from consideration of the randomness of the wave amplitudes and have shown that the standard error of a harmonic analysis is reduced the longer the record; also that the narrower the spectrum the greater is the proportional error. This has been summarised by Deacon [10] as follows: "If the wave spectrum is narrow the mean wave heights evaluated from 10 minutes records may easily differ by as much as $25 \%$. The probable error becomes smaller as the spectrum gets wider. It means that a 10 minute record is not a very accurate guide to what will happen during the next 10 minutes, or to what is happening during the same 10 minutes a mile or so away." This, of course, refers to saccessive 10 minutes records. Actually a 20 minutes record is quite adequate to cover this contingency for most practical purposes.

In so far as spacing of records is concerned, this depends upon the detail wanted in the picture of any wave sequence from a storm centre. Even where data are desired for the derivation of wave forecasting formulae the most practical spacing is two hourly, even though Barber and Ursell [4] have indicated for cerlain criteria of phase shift (which causes blurring) and significant changes in the frequency band that successine sections of the record should be analysed.

A note should be made here of the practice of some engineering firms who place a recorder outside a harbour in order to ascertain the probable maximum wave height for purposes of breakwater design, etc. Such records should be taken over a number of years to be truly representative. Also, as measurements are made for 


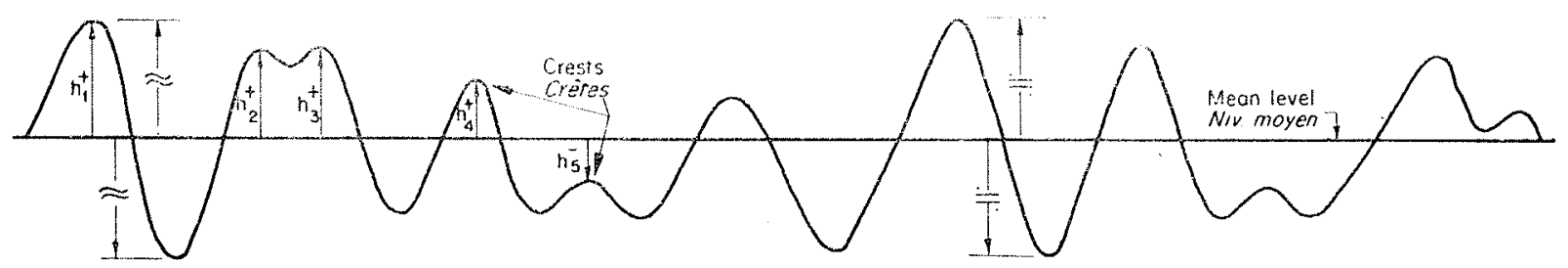

Frg. 10. - Profil complexe montrant la fagon de mesurer la houle et de calculer la largeur du spectre.

A complex wave pattern showing the method of wave measurement and computation of spectral width.

Il convient de mentionner ici la pratique adoptée par certaines entreprises de travaux publics et consistant à placer un enregistreur en dehors d'un port pour connaître la hauteur maximum probable de la houle et pour choisir, par exemple, les caractéristiques d'un brise-lames, etc. Pour que des enregistrements de ce genre aient de la valeur, il faudrait les étaler sur plusieurs années. D'autre part, comme les mesures ne prennent qu'une courte fraction de la totalité du temps, il conviendrait de calculer une valeur moyenne, à partir de laquelle on obtiendrait, par des procédés théoriques, l'amplitude maximum.

Cartwright et Longuet-Biggins [7] ont étudié le cas des spectres de différentes largeurs, où les hauteurs des crêtes au-dessus du niveau moyen sont à considérer plutôt que la hauteur séparant une crète d'un creux. Cela fait, on déduit une relation théorique entre les valeurs du maximum et de la moyenne carrée (*), relation valable seulement pour des nombres de vagues donnés et pour une largeur donnée du spectre.

On pourra tracer sur l'enregistrement le niveau moyen en joignant les milieux des distances entre crêtes et creux, dans les sections du tracé où celles-ci marquent une valeur maximum (fig. 10). La largeur du spectre pourra être appréciée en calculant:

$$
W=\sqrt{1-(1-2 r)^{2}},
$$

où $r$ est le rapport entre le nombre de crêtes situées en dessous du niveau moyen et le nombre total de crêtes figurant sur le graphique (fig. 10). Les courbes correspondant à $W=0,1 / 3$ et $2 / 3$ sont reproduites sur la figure $10(W=1$ est la limite supérieure). Quand $W$ tend vers 0 , le profil de l'onde approche de la forme sinusödale et représente un spectre très étroit; le cas a été étudié par Longuet-Higgins [26] qui a pu utiliser les hauteurs mesurées entre crête et creux,

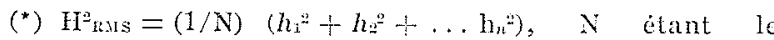
nombre de crêtes (y compris celles au-dessous du niveau moyen, considérées comme négatives), et $h$ la hauteur séparant le niveau moyen de chaque erète (RMS = Root Mean Square $=$ moyenne carrée. $-N$. d $-T$.). only a short percentage of total time, it is deemed advisable to calculate some average value from which the maximum wave height is obtainable theorelically.

Cartwright and Longuet-Higgins [7] have treated the case of spectra of any width, in which it is necessary to consider the heights of wave crests above the mean level rather than the crest to trough height. When this is done a theoretical relationship between the maximum and root mean square values (*) is determined uniquely" for given numbers of waves and given width of spectrum.

The mean level can be plotted on the wave record by joining the mid-crest-to-trough distance occurring in the sections of record where the maximum values of these occur (see fig. 10). The width of the spectrum can be gauged by calculating :

$$
W=\sqrt{1-(1-2 r)^{2}}
$$

where $r$ is the ratio of the number of crests which appear below the mean level to the total number of crests in the record (see fig. 10). Curves $f_{0} r^{\circ} W=0,1 / 3$ and $2 / 3$ are graphed in figure 11 . ( $W=1$ is upper limit.) As $W \rightarrow 0$ the wave profile approaches a sinusoidal form and is representative of a very narrow spectrum; this case was studied by Longuet-Higgins [26], in which wave heights measured from crest-totrough could be used since they were twice the distance from mean level to the crests in a sinusoidal wave. For conditions in which $W$ is not approaching zero the crest-to-trough height is not easily obtainable but if the maximum reach of the wave crest from the mean level is insufficiently informative for a design purpose, then it is reasonable to assume that the measurement represents one half of the crest-to-trough height.

(*) $\mathrm{H}^{2}$ mas $=(1 / \mathrm{N})\left(h_{1}{ }^{2}+h_{2}{ }^{2}+\ldots h_{n}{ }^{2}\right)$, where $\mathrm{N}$ is the number of crests (including those below the mean level which are negative) and $h$ is the vertical distance from mean level to each crest. 


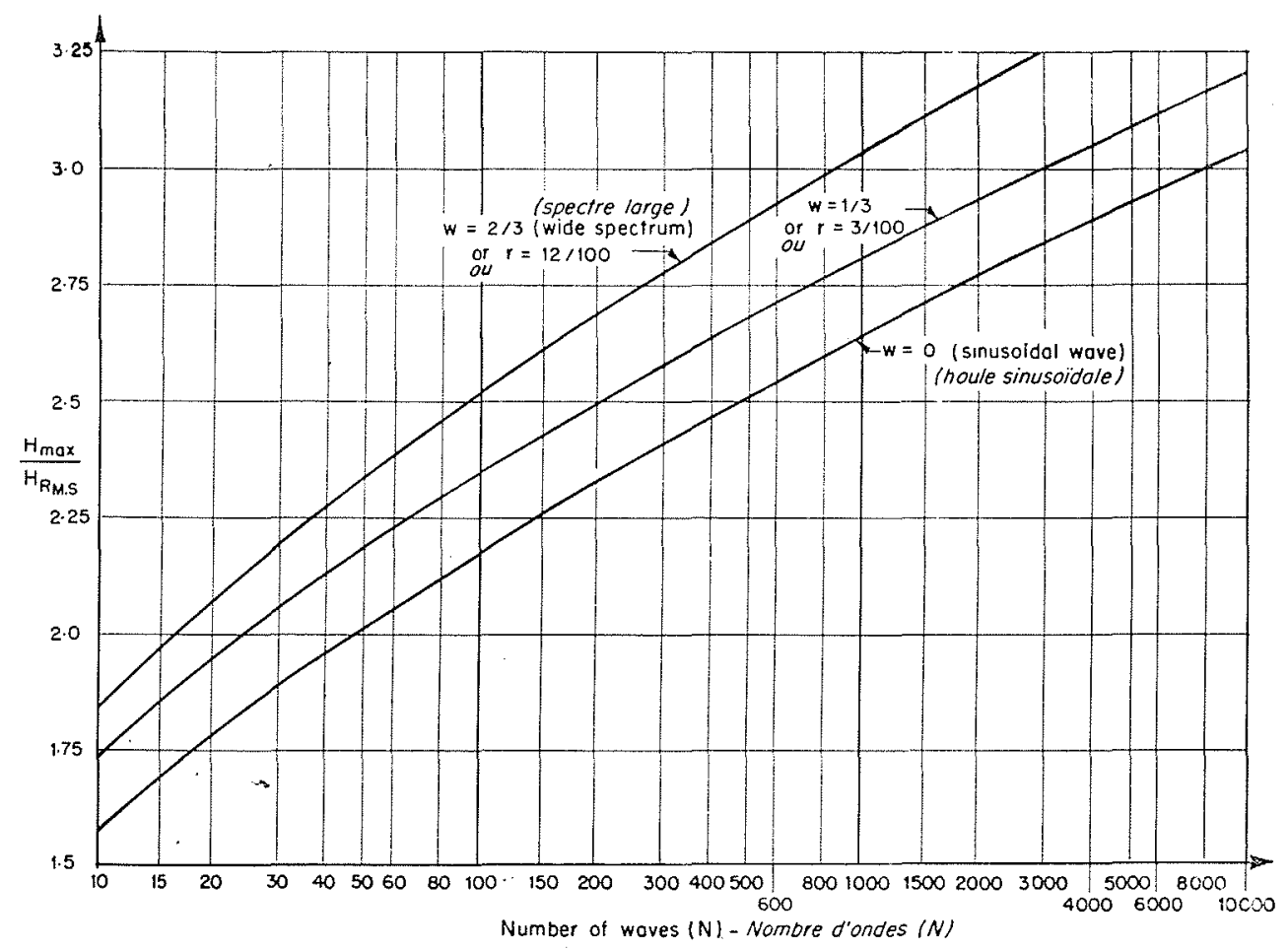

FIG. 11. - Rapport $\mathrm{H}_{\mathrm{max}} / \mathrm{Fims}_{\text {mas }}$ pour divers nombres d'ondes pris dans un enregistrement (d'après la référence 7 ).

Ratio of $\mathrm{H}_{\mathrm{m}: \mathrm{x}} / \mathrm{H}_{\text {nass }}$ for various numbers of waves in a record (from Reference 7 ).

puisqu'elles sont le double de la distance entre le niveau moyen et les crêtes dans une houle sinusoïdale. Quand W n'est pas voisin de zéro, il n'est pas facile d'obtenir la hauteur entre crête et creux, mais si la hauteur maximum de la crête depuis le niveau moyen ne suffit pas à l'établissement d'un projet, on peut admettre de prendre la valeur mesurée comme représentant la moitié de la hauteur entre la crête et le creux.

On portera les deux valeurs de $H_{\max }$ (mesurée et calculée), en fonction du temps, comme sur la figure 12, pour toute la durée de la perturbation cyclonique ayant engendré la houle. Une ligne passant par ces points montrera si la valeur maximum de $H$ est effectivement présente sur l'un des enregistrements. En se rapportant à la carte météorologique synoptique sur laquelle figure la perturbation, et en comparant à d'autres situations météorologiques passées, on verra si les maxima de houle enregistrés pendant une période doivent être majorés. On déduira la façon de tirer des renseignements sur le régime du vent d'après les cartes météorologiques, en consultant les nombreux écrits sur la prévision de la houle, résumés par Saville $[37]$.
Both values of $\mathrm{H}_{\max }$ (measured and calculated) should then be plotted against time as illustrated in figure 12 for the duration of the cyclonic disturbance causing the waves. A line drawn through these points will show whether the maximum value of $H_{\text {max }}$ actually appeared in any of the recordings. Reference to the synoptic weather chart which recorded the disturbance and a comparison with other historic charts will

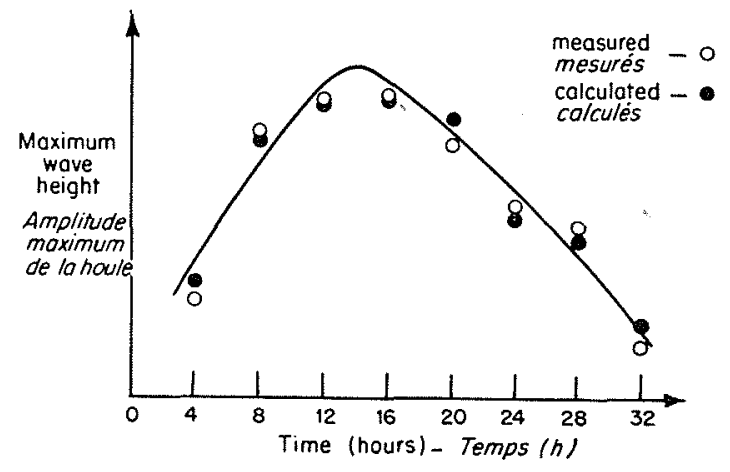

Fig. 12. - Graphique hypothétique montrant Ies hauteurs de vague maxima obtenues dans une succession de vagues de tempête.

Hypothetical record of maximum wave heights obtained during a sequence of storm waves. 


\section{Courants de marée.}

La houle se superposant aux courants de marée subit de nombreuses altérations; les enregistrements qui la concernent peuvent donner une fausse idée des conditions en profondeur infinie, au large des cotes.

Unna [48] a été le premier à ćtudier l'efret des courants de marée sur la houle. Considérant une houle en régime permanent, il montra comment un courant de direction contraire peut arrêter la progression des vagues, et, en accentuant leur cambrure, provoquer leur déferlement; plus la houle est longue, plus fort doit ètre le courant pouvant créer ce phénomène. Au renversement de la marée, le courant de flot améne de nouvelles vagues vers celles qui sont plus près de la côte et qui ont été ralenties par le jusant, Il en résulte un état extrêmement complexe de la mer durant peu de temps. Evidemment, les renseignements qu'on pourra obtenir de l'étude de la houle dans de telles conditions conduiraient à des conclusions complètement erronées en ce qui concerne les conditions régnant en haute mer.

Unna a également remarqué que ce n'est qu'au moment de l'inversion de la marée que les périodes enregistrées seraient fausses. II comparait ce fait au cas de personnes empruntant successivement un ascenseur qui modifierait sa vitesse entre leur entrée et leur sortie. Leurs sorties se succéderaient à des intervalles de temps différents de ceux de leur entrée.

Johnson [24] a examiné l'effet des courants de marée se présentant sous un certain angle relativement à la houle; il a, lui aussi, considéré le régime permanent. Il nota comment, lors de la pénétration de la marée dans un port ou un fleuve, les vagues peuvent se cambrer avec le jusant et s'allonger avec le flot. Il nota également qu'un fort courant le long de la côte est capable de dissiper des vagues de période courte en ne laissant atteindre la plage que les vagues de période longue. Ces quelques exemples font voir que l'on ne doit pas placer les enregistreurs de houle à l'extrémité d'un briselames ou de jetées où il peut y avoir des courants de marée ou des « rip currents ».

Barber [3] a abordé la question de la perpétuelle variabilité des choses de la nature, sous un angle plus nettement mathématique. Il montra que « la longueur moyenne des vagues appartenant à un groupe augmente ou diminue de la même façon que l'ensemble de la surface de l'eau sur laquelle le groupe se déplace. "D'ordinaire, quand la houle monte avec le flot, $T$ diminue tandis que $\mathrm{L}$ reste constant; l'accroissement de profondeur fait augmenter $L$ laissant $T$ constant. indicate whether the maximum waves recorded during any period are likely to be exceeded. The method of extracting wind data from synoptic weather maps can be ascertained from the many papers on wave forecasting which have recently been summarised by. Saville [37].

\section{Tidal Streams.}

Waves propagated into tidal streams undergo several changes, which, if recorded, can give quite erroneous information about conditions in the deep slack water offshore.

Unna [48] first discussed the effect of tidal streams on waves. From a consideration of a steady state he illustrated how a contrary stream could stop the forward motion of waves and, with the resultant steepening, cause them to break; the longer the wave the stronger was the current required to effect such dissipation. On the turn of the tide, the flooding stream carries new waves into others nearer the coast which have been slowed up on the ebb. This causes an extra complex sea for a short period. It is obvious that for waves recorded under these circumstances completely wrong inferences could be drawn about the open sea conditions.

Unna also noted that it was only on the change of tide that the recorded periods would be in error. He likened the situation to people travelling on an escalator which changes speed between the time they enter it and the time they leave it. They are discharged at time intervals different from those at which they embarked.

Johnson [22] discussed the effect of tidal currents at an angle to the waves; steady state conditions were again considered. He noted how, at tidal entrances to harbours or rivers, waves can be steepened on the ebb and drawn inwards on the flood. He also pointed out that a strong longshore current can dissipate short period waves and allow only long period waves to reach the beach. These instances point out that wave recorders should not be placed off the end of breakwaters or groynes where tidal or rip currents are likely to occur.

Barber [3] with a more vigorous mathematical approach, treated the continously variable situation that pertains in nature. He showed that "the average length of the waves in the group expands or contracts at the same rate as the general surface of the water upon which the group is moving ". Generally, when waves are carried upwards on a flood tide $\mathrm{T}$ decreases whilst $L$ remains constant; and the increase of depth causes an increase in $L, T$ remaining constant. 
Ainsi done, la question est très compliquée en ce qui concerne l'amplitude de la houle; naturellement, la période de la houle change constamment. Mais, comme conclut Barber, « quand des groupes de vagues achèvent de traverser une aire soumise a la marée en une fraction du cycle de marée, la période apparente variera relativement peu », Il recommande donc de placer les enregistreurs à l'endroit le plus étroit du plateau continental. Il serait également souhaitable, si l'on ne dispose pas d'endroit exempt de marée, d'enregistrer les valeurs à certains moments le long du cycle de marée, de façon à pouvoir en tirer, autant que possible, des moyennes.

\section{Les conditions aux estuaires.}

Tout ce qui a été dit au chapitre 10 s'applique également aux estuaires où, en plus des conditions qui régissent la marée, il existe un apport d'eau douce. Les effets de celui-ci consistent à accroître la célérité superficielle du courant de jusant et à abréger la période du courant de flot à la surface. En effet, l'eau douce débouche à l'instar d'une langue près de la surface à l'embouchure et peut continuer à couler après que le flot aura introduit en coin une masse d'eau salée dans l'estuaire. Les deux courants, la langue d'eau douce et le coin d'eau salée, peuvent se rencontrer; au point de leur rencontre, il se produira une forte turbulence, les vagues étant entrainées dans un dissipateur improvisé.

Les estuaires sont également caractérisés par leurs faibles profondeurs et la houle subira une réfraction vers les rives, réfraction variable dans le temps selon les fluctuations du courant de marée. Nous avons déjà examiné, au chapitre 10 , les effets de pareils courants «latéraux».

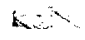

\section{Surélévations de niveau dues aux tempêtes.}

De nombreux mémoires ont été consacrés à la propriété des centres cycloniques de surélever temporairement le niveau des caux au voisinage de la côte, soit par suite des efrorts tangentiels que le vent exerce sur son parcours direct vers le rivage, soit par suite du passage effectif d'une dépression le long du rivage. Cette surélévation se manifeste surtout dans les zones où l'eau est confinée et ne peut s'échapper du point critique vers une direction quelconque. Si elle coïncide par hasard avec une forte marée et est accompagnée de très grosses vagues, comme c'est souvent le cas, elle pourra provoquer des inondations catastrophiques. Tout le monde se souvient du débordement désastreux de la mer du Nord en 1953. Depuis, la majorité des pays environ-
Thus conditions are extremely complicated as far as wave height is concerned and, of course, the wave period is changing continuously. But as concluded by" Barber "when wave groups complete their passage through a tidal area in a fraction of a tidal cycle the change in apparent period will be proportionally small". He thereFore advises the location of recorders at the narrowest possible part of the continental shelf. It would seem advisable also, if a non tidal site is unavailable, to take records at specific times throughout a tidal cycle in order to average conditions as much as possible.

\section{Estuarine Conditions.}

All the arguments contained in section 10 apply also to estuaries where, not only tidal conditions operate, but also fresh water discharges exist. The effect of the latter is to increase the surface velocity in the ebb stream and to shorten the period of the flood stream at the surface. This occurs because the fresh water issues as a tongue near the surface of the mouth and can continue to flow after the flood tide has caused a salt-water wedge to penetrate the mouth. It is possible that the two streams (fresh water and salt water wedge) could meet, at which point there would be a great turbulence with waves being carried into a ready made dissipator.

Estuaries are also notable for their shallowness and waves will be refracted towards the shores by amounts varying with time according to the tidal current running at the moment. The effect of such "side" currents was discussed in Section 10 .

\section{Storm Surges.}

Many papers have been written on the ability of cyclonic centres temporarily to build up water levels on a coast. This is accomplished, either by tangential stress of the wind over a fetch oriented directly onshore, or by the actual "low pressure" moving across the coastline. "This surge or "set-up" is most prevalent in confined sea areas where the water is prevented from escaping to either side of the critical point. If they occur concurrently with a high tide and are accompanied by the usual mountainous waves catastrophic flooding is likely. The disastrous North Sea surge of 1953 is well known. Most of the countries bounding this area now have warning systems actuated by tidal fluc- 
nants ont établi des systèmes d'alerte déclenchés suivant les fluctuations de la marée et de la direction ou des vitesses du vent en provenance de directions particulièrement dangereuses.

Même des côtes rectilignes, qui ne favorisent pas par leur lopographie cette concentration d'énergie, peuvent subir de telles surélévations dies au vent lors des plus fortes tempêtes. Les vagues peuvent ainsi atteindre des ouvrages ou des installations côtiers situés à des niveaux normalement inaccessibles. Si done un enregistreur de houle comporte un dispositif d'élimination des variations à longue période du niveau de l'eau, comme par exemple les marées ou les surélévations dues au vent, ses enregistrements devront être lus conjointement avec les données d'un marégraphe.

\section{Enregistrement de la houle en surface. ou au fond.}

De ce qui précède, on peüt déduire que les enregistreurs de pression au fond ne peuvent donner une image exacte de la houle de surface. Certes, les distorsions propres aux seules fluctuations de pression se limitent à l'amortissement avec la profondeur, aux fréquences doubles liées aux ondes stationnaires, peut-être. aussi aux surélévations dues au vent, mais ces facteurs suffiraient pour que des conclusions erronées soient tirées des profils obtenus et de leur analyse.

Toutes les autres erreurs sont communes, à des degrés différents, à l'enregistreur de surface et à l'enregistreur de fond et sont principalement dues à une mauvaise implantation de l'appareil. En réalité, l'enregistreur de surface aura surtout à souffrir de la présence d'harmoniques dus à la cambrure du profil enregistré; comme toutes les houles de période courte sont enregistrées, il peut être très malaisé de séparer le réel du fictif.

Or, dans le choix de l'enregistreur destiné à un cas déterminé, les raisons économiques et les particularités de l'installation et de l'entretien jouent un rôle prépondérant parmi les nombreux iacteurs à considérer; la qualité de l'enregistrement passe ainsi au second plan. Même alor's, les recommandations qui suivent peuvent être de quelque utilité.

Il a déjà été dit que l'enregistreur de pression tend à attribuer à la hoùle une forme sinusoïdale se prêtant facilement à l'analyse harmonique. On sacrifie ainsi le vrai profil de surface; en effet, bien que nous connaissions le facteur d'amortissement théorique dans certaines conditions très limitées, son application est loin d'être satisfaisante dans le cas des houles irrégulières. Morison [28], Timme et Stinson [43], ainsi que Fuchs [16], ont montré qu'il tuations and wind velocity readings from particularly dangerous directions.

But even a straight length of coast, without topography to concentrate such energy, can suffer from wind set-up at the time when the waves are highest. This permits them to reach higher structures or coastal features than they normally do. Therefore, if a wave recorder contains a device for filtering out long term changes in water level, such as tides and wind setup, the recordings should be read in conjunction with tide gauge data.

\section{Pressure or Surface Wave Record.}

It appears from the foregoing that bottom pressure recorders cannot reproduce a true picture of surface wave conditions. Even though the only distortions which affect them alone are depth attenuation, double-frequency pressures from standing waves, and perhaps wind set-up, these are of such consequence that many erroneous conclusions can be drawn from their profiles and analyses.

All other errors affect both the surface and the bottom pressure recorder in varying degrees, and are mainly due to bad siting of the instrument. In fact, the surface wave recorder may suffer the most from harmonics produced by steepness of the recorded profile and since short period waves are already recorded, great difficulty may be experienced in separating the real from the phoney.

But, in choosing a recorder for a particular task, economics and hazards of installations or maintenance rate highly in the many factors to be considered. The quality of the record thus assumes a minor role. Even so, the following summary may be of some assistance.

It has been indicated that the pressure wave recorder tends to give a sinusoidal wave form which is very adaptable to harmonic analysis. This is obtained at the expense of the actual surface profile, because, although the theoretical attenuation factor is known for some very limiting conditions, its application to irregular wave patterns is far from satisfactory. As shown by Morison [28], Timme and Stinson [43] and Fuchs [16], it is relatively easy to compute bottom pressure fluctuations from a given surface profile but the reverse procedure is not so definite. It is important to note that [36] "The Hydrographic Office has not used bottom pressure records as a method of determing sea sur- 
est assez facile d'évaluer les fluctuations de la pression de fond d'après un profil de surface donné; mais le contraire l'est moins. Il importe de noter [36] que « le Bureau Hydrographique a utilisé les enregistrements de la pression de fond moins pour déterminer les conditions à la surface que comme une source d'information pour l'élaboration d'une technique de la prévision des pressions de fond $\gg$.

Si l'on ne cherche à obtenir que la hauteur maximum ou quelque autre hauteur caractéristique, on devra donner la préférence à l'enregistreur de surface. Si la période est aussi importante que l'amplitude, l'enregistreur de pression est à recommander; bien entendu, on aura à faire l'analyse harmonique de ses données. En général, il convient donc de préférer les enregistreurs de surface quand c'est l'amplitude qui importe devantage, surtout par houle de courte période; si, par contre, c'est la connaissance de la période que l'on recherche surtout, en particulier pour une houle à longue période, l'enregistreur de pression parait préférable. Dans ce. dernier cas, il semble souhaitable de perfectionner l'application du facteur de réponse de la pression.

La plupart des erreurs d'enregistrement de houle sont à attribuer à des conditions locales; il faut donc que les auteurs qui exploitent les résultats obtenus communiquent aussi toutes les précisions voulues sur l'installation d'enregistrement et indiquent les dispositions prises pour éliminer ou réduire les erreurs qui interviennent.

\section{De la grandeur des erreurs.}

Dans la détermination de la période, l'erreur provenait autrefois de l'amortissement des houles de période courte par les enregistreurs de pression et aussi des incertitudes qui apparaissaient avant que l'on se livre à l'analyse harmonique des profils obtenus. Avec les moyens actuels de l'analyse spectrale, la période peut être bien plus exactement déterminée que la hauteur. Il convient cependant de noter qu'il n'a pas encore été possible de préciser completement le facteur de réponse de la pression, car beaucoup des erreurs mentionnées précédemment ont pu entacher les valeurs obtenues. Tant que la vérification n'aura pas été faite au laboratoire sur une houle irrégulière, on ne devra pas s'attendre à une précision dépassant $25 \%$.

Cette erreur de $25 \%$ est surtout due à la cambrure de la houle, introduisant un effet secondaire dans les fluctuations de la pression et des harmoniques dans l'analyse. Une autre source d'erreurs pouvant devenir notable est due ̀̀ la face conditions but rather as a source of data for the development of techniques for prediction of bottom pressures."

If only maximum height or some other representative height is required then a surface wave recorder is preferable. If wave period is as important as wave height then a pressure wave recorder is suggested and, of course, the results should be analysed harmonically. In general, therefore, where height information is important, especially where short period waves predominate, surface wave recorders are desirable; and where period information assumes importance, especially in long period swell, pressure wave recorders appear most suitable. In the latter, case, improvements in the application of the pressure response factor seem desirable.

Many of the inaccuracies of wave recording can be attributed to site conditions and it seems advisable that authors using such data should give the fullest account of the recorder installation and the steps taken to eliminate or reduce the errors that do arise.

\section{Magnitude of Errors.}

The error in period determination in the past has occured because of short period wave attenuation by pressure recorders and the lack of definition before harmonic analysis was applied to the profiles obtained. Now, that spectral analysis is possible, period determination is much more accurate than height determination. It is reasonable to state that a thorough check on the pressure response factor has not been made because many of the other errors described in this paper may have entered the results. Until such a check is conducted in the laboratory with an irregular wave pattern no better accuracy than $25 \%$ can be expected.

The most important source of this $25 \%$ error is the steepening of waves, which introduces a second order effect into the pressure fluctuations and causes harmonics in the analysis. Another source which can be substantial is that due to refraction. If a site cannot be chosen to avoid this, then refraction coefficients should be calculated and applied to the heights of each wave component. This prestupposes a hamonic analyses and knowledge of the incident angle of the waves, the latter requiring reference to the synoptic weather charts until a suitable wave direction recorder is invented,

Assuming that obvious reflective surfaces are avoided in the vicinity of the recorder, the coef- 
réfraction. Si l'on ne peut choisir un emplacement de manière à l'éviter, on devra calculer les coefficients de la réfraction et les appliquer à chacune des hauteurs de chacune des composantes de la houle. Cela présuppose une analyse harmonique, ainsi que la connaissance de l'angle d'incidence de la houle, donc le recours aux cartes météorologiques d'ensemble tant qu'on n'aura pas inventé un enregistreur satisfaisant de la direction de la houle.

Dans l'hypothese qu'il n'y a pas de surface réfléchissante évidente dans le voisinage de l'instrument, on pourra déterminer, d'après la figure 6 , les coefficients de réflexion dus aux plages et en déduire la hauteur de la houle incidente. C'est particulièrement important quand la distance entre l'instrument et la côte est un multiple de la demi-longueur d'onde. Quant aux houles dont l'instrument occupe un des Doints nodaux, on aura peutxêtre à amplifier la hạteur enregistrée.

A l'aide de la figure 9, on évaluera les hauteurs des harmoniques de manière à pouvoir ensuite calculer l'amplitude exacte des houles de surface de même période, s'il en existe.

Comme dans toute méthode comportant un échantillonnage, l'importance et la fréquence des observations influent sur le résultat. Le degré d'exactitude cherché dépend donc de l'usage qu'on veut faire des valeurs mesurées. Un enregistrement de 10 minutes peut introduire des erreurs fortuites de $15 \%$ et plus, un enregistrement de 20 minutes représente la durée optima pour des houles comprises dans le « fetch », un de 30 minutes pour la houle correspondant à une tempête à 2000 miles. Dans ces deux derniers cas, on devra réduire la longueur de l'enregistrement quand la bande centrale des périodes atteint l'instrument, si on peut la saisir.

Autant que possible, on évitera de choisir les points d'enregistrement à l'intérieur des estuaires ou sur des côtes soumises à de fortes marées. Pour un enregistrement s'étendant sur 20 minutes, les périodes de la houle ne semblent pas devoir se ressentir grandement de l'amplitude de la marée; toutefois, l'influence que celle-ci exerce sur les hauteurs est si complexe que l'erreur introduite est difficile à apprécier.

\section{Conclusions et quelques recommandations.}

On ne saurait considérer comme se cumulant toutes les erreurs précitées, mais on n'épargnera pas les efforts pour les éviter. Il y a lieu de conseiller (fig. 3 et 9 ) de choisir pour les houles ficients of reflection from beaches can be ascertained from figure 6 and so the incident wave heights obtained. Especially is this important for those waves for which the distance from instrument to shore is a multiple of the half wave length. Waves for which the recorder may be at a nodal point may require some applification of the recorded height.

Figure 9 permits the computation of the heights of the harmonics so that, should surface waves of similar period be present, their correct amplitude can be calculated.

As with all sampling methods the size and spacing of the samples will influence any result. The desired accuracy, therefore, depends upon the use for which the data is obtained. It has been shown that a 10 minute record can introduce random errors of $15 \%$ or more and that a 20 minute record is the optimum length for waves within a fetch, 30 minutes for swell for a storm 1000 miles distant and 45 minutes for one 2000 miles distant. In the latter two cases the length of record should be reduced as the middle band of periods reach the recorder, if this is observable at the time.

If it can possibly be avoided, sites should not be chosen within estuaries or coastal waters which are subject to large tidal fluctuations. For a 20 minute record the wave periods are not likely to be affected greatly by tidal range, but the influence on wave heicht is so complicated that the error introduced cannot readily be assessed.

\section{Conclusions and Recommendations.}

The errors noted above cannot all be considered cumulative but every effort should be made to avoid them. It is suggested (see fig. 3 and 9) that a depth of 50 feet be used for ocean waves, or more generally, a value of $d / L=0.125$. Figure 1 will indicate the wave periods which will be omitted from the record. It is also suggested that, if possible, the instrument be located on the seaward extremity of an offshore island (see fig. 13) at a point where the bottom contours are close and any cliffs will reflect the waves away from the recorder. Such sites are not uncommon.

Even where wave information is required or a particular harbour site only, it is preferable to get such "upon sea" information, because wave conditions may change substantially once maritime structures have been built and so the ori- 
océaniques une profondeur de 50 pieds $(15 \mathrm{~m})$ ou, plus généralement, de se donner $d / \mathrm{L}=0,125$. D'après la figure 1 , on saura quelles sont les périodes qu'il faut exclure du relevé.

Il est d'autre part recommandable de placer si possible l'instrument sur le côté tourné vers la mer de l'extrémité d'une île du large (fig. 18) en un point où les contours du fond se resserrent et où les réflexions sur les rochers tendent à éloigner les houles de l'enregistreur. Il n'est pas rare de rencontrer des sites pareils.

Même pour recueillir seulement les renseignements nécessaires à l'établissement d'un port donné, il convient d'adopter les valeurs obtenues en pleine mer; les caractéristiques de la houle peuvent en effet être sensiblement modifiées $d u$ fait de la construction des ouvrages maritimes enlevant l'intérêt des mesures préalables, à moins qu'elles n'aient été faites en eau profonde.

Les emplacements'à éviter pour les stations d'enregistrement sont :

1) Les eaux trop basses ou très profondes;

2) Les baies abritées dọnant lieu à réfraction, ou à diffraction;

3) Le côté sous le vent des îles, où prédominent les houles stationnaires;

4) La proximité de surfaces réfléchissantes, telles que digues, falaises ou brise-lames;

5) La proximité d'extrémités des brise-lames ou d'épis, susceptibles d'être le siège de courants de retour, ou de courants liés à un fleuve ou à la marée;

6) Les estuaires ou les zones sujettes à des courants anormaux;

7) Les régions à fond meuble constitué de vase ou d'algues marines.

Si les résultats recueillis sont destinés à établir des formules de prévision de la houle, il faut que les mesures et l'analyse soient faites avec le plus grand soin. Il ne suffit pas de faire usage des outils statistiques les plus récents quand il s'agit de valeurs tellement dispersées que l'on en déduirait tout ce qu'on veut. Les équations ainsi obtenues donnent lieu à de fortes dispersions et peuvent recéler des erreurs pendant longtemps. Un palliatif de cet état de choses consiste à donner le plus de précisions possible sur les méthodes suivies pour obtenir les valeurs caractérisant la houle, de manière que l'usager puisse juger lui-même des mérites de l'observation.

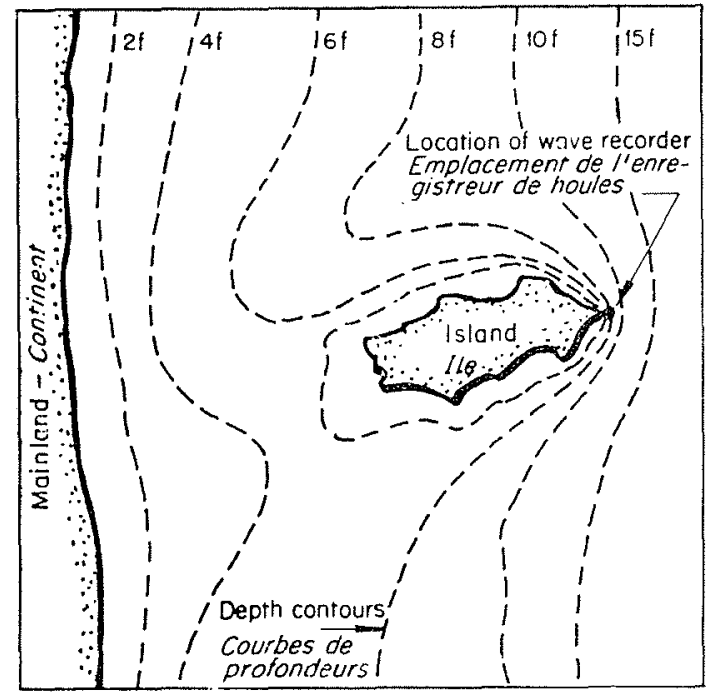

Fia. 13. -- Vue en plan d'une disposition iscale d'un enregistreur permettant d'obtenir les caractéristicues de la houle le long d'un littoral étendu.

Plan showing an ideal location for a recorder in order to obtain deep water wave data for a comprehensive length of coastline.

ginal wave data is useless unless it refers to deep water.

Recorder sites to avoid are:

(i) very shallow or very deep water,

(ii) sheltered bays where refraction or diffraction occur,

(iii) the leeside of islands where standing waves are prevalent,

(iv) offshore from reflecting surfaces such as sea-walls, cliffs or breakwaters,

(v) offshore from the ends of breakwatters or groynes where rip currents, river discharge or tidal streams can occur,

(vi) in estuaries or areas subject to abnormal currents,

(vii) on non-rigid areas of the ocean bed, such as mud or seaweed deposits.

Where wave data are used to aid in the derivation of wave forecasting relationships it is imperative that the utmost care be taken in their measurement and analysis. It is not sufficient to apply the latest statistical tools to data that are so scattered that anything could be read into them. Such equations become widely dispersed and errors can linger for a long time. One paliative to this situation is for the fullest information to be published on the method of obtaining the wave data, so that users may assess for themselves the merit of the observations. 


\section{Remerciements}

L'auteur a composé le présent mémoire pendant qu'il bénéficiait d'une bourse Maude Gledden délivrée par l'Université de l'Australie Occidentale. Il exprime sa profonde gratitude envers le National Institute of Oceanography de Wormley (Angleterre) pour les facilités qui lui ont été accordées pendant son travail et au personnel avec qui il a en des discussions utiles. En particulier, il remercie M. M. J. 'Tucker et le Dr M.S. Longuet-Higgins pour l'aide qu'ils lui ont apportée dans cet ordre d'idées, et aussi pour la révision du manuscrit. Il remercie également le $\mathrm{D}^{r}$ G.E.R. Deacon, directeur de l'Institut précité, qui en a supervisé la rédaction.

\section{Acknowledgements}

'This paper was written whilst the author was holder of a Maude Gledden Fellowship from the University of Western Australia. Deep appreciation is felt for the facilities provided at the National Institute of Oceanography, Wormley, England where the paper was prepared and for the helpful discussions with members of the staft there. In particular the author would like to thank Mr. M.J. Tucker and Dr. M.S. LonguetHiggins for their assistance in this way and also for checking the manuscript. The author is also appreciative of the supervision of Dr. G.E.R. Deacon the Director of the Institute.

\section{BIBLIOGRAPHIE - BIBLIOGRAPHY}

[1] Abramson (H. N.) and. Bretschneider (C. L.). Some observations concerning the analysis of surface waves when the bottom is non rigid Beach Erosion Board., Tech. Mem. No. 46. (Appendix I), 1954.

[2] AIRY (Sir G. B.), - Tides and Waves, 1845

[3] Barber (N. F.). - The behaviour of waves on tidal streams. Proc. Roy. Soc., A, Vol. 198, 1949, p. 81.

[4] BARber (N. F.) and Ursel (F.). - The generation and propagation of waves and swell. Phil. Trans., A, Vol. 240 , No. 824,1948 .

5] Barber (N. F.), Uhsell (F.), Darbyshine (J.) and Tucker (M. J.). - A frequency analyser used in the study of ocean waves. Nature, Lond. Vol. 158 , 1946 , p. 329 .

[6] Bowden (K. F.). - Some observations of waves and other fluctuations in a tidal current. Proc. Roy. Soc., A, Vol. 192, 1948, p. 403.

[7] Cartwhight (D. E.) and Longuex-Higgins (M. S.).-The statistical distribution of the maxima of a random function. Proc. Roy. Soc., A, 237; 1956, p. 212.

[8] Chrne (A. J.). - Summary report on shore wave recorder mark III. Vniv. of California, HE-116303,1949 .

[9] Cooper (R. IB.) and Longuet-Higins (M. S.). - An experimental study of the pressure variations in standing water waves. Proc. Roy. Soc., A, Vol. 206, 1951 , p. 424 .

10] Deacon (G. E. R.). -- Marine physics. Proc. Inst. Civil Engineers, 1956. Part 1, Vol. 5, p. 661.

[11] Donn (W. L.). - Studies of waves and swell in the western north atlantic. Trans. Amer. Geophys. Un., Vol. 30, No. 4, 1949, p. 507 .

[12] Ewing (M.) and Press (F.). - Notes on surface Waves. Ann. N. Y. Acad. Sci., Vol. 51, Art. 3, 1949. p. 453. (Ocean surface waves, edited by B. HaunwITZ).

[13] Forsom (R. G.). - Sub-surface pressures due to oscillatory waves. Trans. Amer. Geophys. Un., Vol. 28, No. 6, 1947, p. 875 .

[14] - Discussion of ref. 33. Trans. Amer. Geophys. Yn., Vol. 29 , No. 4, 1948, p. 588 .

[15] - Measurement of ocean waves. Trans. Amer. Geophys. Un., Vol. 33, No. 5, 1949, p. 691.

[16] Fuchs (R. A.). - On the theory of irregular waves. Proc. First Conf. on Ships and Waves 1954, p. 1 , 1955.
[17] GerhaRdT (J. R.), Jrhy (K. H.) and KaTz (I.). - A comparison of step - pressure - and continuouswire-gauge wave recordings in the Golden Gate Channel. Trans. Amer. Geophys. Un., Vol. 36, No. 2, 1955, p. 235 .

[18] Greslou (L.) and Mahé (Y.). - Etude du coefficient de réflexion d'une houle sur un obstacle constitue par un plan incline. (Study of the reflection coefficient of a wave on an inclined plane). Proc. Fifth Conf. on Coastal Eng. 1954, p. 68,1955 .

[19] Healy (J. J.). - Wave damping effect of beaches. Proc. Minnesola International Hydraulics Convention 1953 , p. 213.

20]. Horne (J. W.) and Krng (G. T.). - The lateral stability of shingle beaches. Proc. Instn. Munic. Engs., Vol. 81, No. 8, 1955, p. 357.

[21] Irubahren (P.) and Nogales (C.).- Limiting batter (slope) between the breaking and reflection of waves. Translation No. 50-2, 1950. Waterways Experimental Station, Vicksburg; Beach Erosion Board Bull., Vol. 5, No. 2, 1951, p. 1.

[22] Johxson (J. W.). - The refraction of surfaco waves by curvents. Trons. Amer. Geophys. Un., Vol. 28 , No. 6, 1947, p. 867 .

[23] - Sand transport by littoral currents. Vniv. of California I.E.R., Series 3, Issue 338, 1952.

[24] L Amb (Sir H.). - Hydrodynamics. Cambridge Uninersity Press, 6th Ed., 1932.

[25] Longuet-Higans (M. S.). - A theory of the origin of microseisms. Phil. Trans., A, Vol. 243, No. 857, 1950 .

[26] - On the statistical distribution of the heights of sea waves, Sears Foundation, J. Mar. Res. Vol. 21 , No. 3,1952, p. 245.

[2] - The refraction of sea waves in shallow water. J. Fluid Mechanics, Vol. 1, Pt. 2, 1956, p. 163.

[28] Monisox (J. R.). - Analysis of subsurface pressurc records in constant depths and on sloping beaches. Univ. of California, I.E.R., Series 3 , Issue 336 , 1952.

[29] NeUmans $\left(a_{0}\right)$. - On wind-generated wave motion at subsurface levels. Trans. Amer. Geophys. Un. Vol. 36, No. 6, 1955, p. 985.

[30] Pierson Jr. (W.J.). - An electronic wave spectrum analyser and it's use in engineering problems. Beach Erosion Board, Tech. Mem, No, 56, 1954. 
(31] Pierson Jr. (W. J.) and Chang (S. S. L.). - A wave spectrum analyser. Proc. First Conf. on ships and waves 1954 , p. $55,1955$.

32] Pierson Jr. (W. J.) and Marks (W.). - The power spectrum analysis of ocean wave records. Trans. Amer Geophys. Un., Vol. 33, No. 6, 1952, p. 834.

[33] PUTz (R. R.). - Idealised reconstructions of ocean surface wayes as inferred from measurements of twenty five subsurface pressure records. Univ. of California I.E.R., Series 3, No. 317, 1950

[34] - Measurement and analysis of ocean waves. Proc. First Conf. on ships and waves, 1954, p. 63, 1955.

35] RaUCH (S.) - Pressure fluctuations at a given depth below the surface of the ocean. Univ. of California, HE-116-191, 1945 .

[36] Roper (J. F.) and Schule (J. J.). - Wave forecasting activities at the Hydrographic Office. Proc. First Conf. on ships and waves 1954, p. 92, 1955.

[37] Savilue Jr. (T.). -- Wave forecasting. proc. First Conf. ships and waves 1954 , p. 78,1955 .

[38] Serwel (H.R.). - Investigations of the underwater pressure records and simultaneous sea surface patterns. Trans. Anter. Geophys. Un., Vol. 28, No. $5,1947, p .722$.

39] - Results of research on surface waves of the western north atlantic. - M.I.T. and Woods Hole, papers in Physical Oceanography and Meteorology, Vol. $\mathrm{x}$, No. 4, 1948
[40] - Evaluation of sea-surface roughness from underwater pressure recordings. Trans. Amer. Geophys. Un., Vol. 29, No. 2, 1948, p. 197.

[41] Snodgrass (F. E.). - Wave measurements. Symposium on Oceanographic Instrumentation 1952, p. 139, NRC. Publ. 309. also Vniv. of Californit I.E.R. Series 3 , Issue 342,1952

[42] Srokes (G. G.). - On the theory of oscillatory waves. Camb. Trans., viii, 1847, (Paper's i, 212).

[43] Thme (R. C.) and Strnson (F. A.). - Preliminary investigations on predicting properties of bottom pressure fluctuations. U.S.H.O., Tech. Rep. 14, 1955

[44] Tucker (M. J.). - Surf beats-sea waves 1-15 minute periods. Proc. Roy. Soc., A, 202, 1950, p. 565 .

[45] - The N.I.o. wave analyser. - First Conf, Coastal Eng. Instruments 1955, p. 129, 1956.

[46] - The Analysis of finite-length records of fluctuating signals. Br. Jr. of App. Phys,, Vol. 8, 1957, p. 137.

[47] TukEY (J. W.). - The sampling theory of power spectrum estimates. Symposium on Application of Autocorrelation Analysis to Physical Problems, Woods Hole, 1949, p. 47.

[48] UnNa (P. J. H.). - Waves and tidal streams. Nature, Lond., Vol. 149, 1942, p. 219.

[4] (Notice Provisoire). - Enregistreur Autonome de Houle, Laboratoire National d'Hydraulique, 1956.

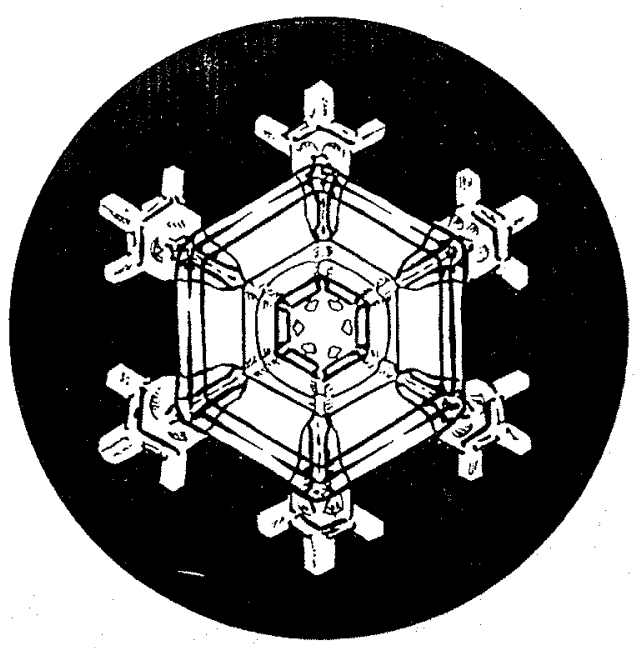

